\title{
Accounting for non-linear chemistry of ship plumes in the GEOS-Chem global chemistry transport model
}

\author{
G. C. M. Vinken ${ }^{1, *}$, K. F. Boersma ${ }^{1,2}$, D. J. Jacob ${ }^{3}$, and E. W. Meijer ${ }^{4}$ \\ ${ }^{1}$ Eindhoven University of Technology, Eindhoven, The Netherlands \\ ${ }^{2}$ Royal Netherlands Meteorological Institute, De Bilt, The Netherlands \\ ${ }^{3}$ Harvard University, Cambridge, USA \\ ${ }^{4}$ TNO, Utrecht, The Netherlands \\ * Invited contribution by G. C. M. Vinken, recipient of the EGU Outstanding Student Poster Award 2011.
}

Received: 27 May 2011 - Published in Atmos. Chem. Phys. Discuss.: 23 June 2011

Revised: 28 September 2011 - Accepted: 7 October 2011 - Published: 23 November 2011

\begin{abstract}
We present a computationally efficient approach to account for the non-linear chemistry occurring during the dispersion of ship exhaust plumes in a global 3-D model of atmospheric chemistry (GEOS-Chem). We use a plume-ingrid formulation where ship emissions age chemically for $5 \mathrm{~h}$ before being released in the global model grid. Besides reducing the original ship $\mathrm{NO}_{\mathrm{x}}$ emissions in GEOS-Chem, our approach also releases the secondary compounds ozone and $\mathrm{HNO}_{3}$, produced during the $5 \mathrm{~h}$ after the original emissions, into the model. We applied our improved method and also the widely used "instant dilution" approach to a 1-yr GEOS-Chem simulation of global tropospheric ozone- $\mathrm{NO}_{\mathrm{x}}$ VOC-aerosol chemistry. We also ran simulations with the standard model (emitting 10 molecules $\mathrm{O}_{3}$ and 1 molecule $\mathrm{HNO}_{3}$ per ship $\mathrm{NO}_{\mathrm{x}}$ molecule), and a model without any ship emissions at all. The model without any ship emissions simulates up to $0.1 \mathrm{ppbv}$ (or $50 \%$ ) lower $\mathrm{NO}_{\mathrm{x}}$ concentrations over the North Atlantic in July than our improved GEOS-Chem model. "Instant dilution" overestimates $\mathrm{NO}_{\mathrm{x}}$ concentrations by $0.1 \mathrm{ppbv}(50 \%)$ and ozone by $3-5 \mathrm{ppbv}$ (10-25\%), compared to our improved model over this region. These conclusions are supported by comparing simulated and observed $\mathrm{NO}_{\mathrm{x}}$ and ozone concentrations in the lower troposphere over the Pacific Ocean. The comparisons show that the improved GEOS-Chem model simulates $\mathrm{NO}_{\mathrm{x}}$ concentrations in between the instant dilution model and the model without ship emissions, which results in lower $\mathrm{O}_{3}$ con-
\end{abstract}

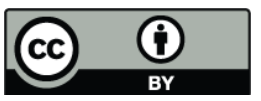

Correspondence to: G. C. M. Vinken (g.c.m.vinken@tue.nl) centrations than the instant dilution model. The relative differences in simulated $\mathrm{NO}_{\mathrm{x}}$ and ozone between our improved approach and instant dilution are smallest over strongly polluted seas (e.g. North Sea), suggesting that accounting for inplume chemistry is most relevant for pristine marine areas.

\section{Introduction}

Seagoing ships carry approximately $90 \%$ of the goods traded globally and the seaborne trade has been estimated to have increased by 5\% per year between 2002 and 2007 (Eyring et al., 2010). These ships emit large quantities of gases and particles into the marine boundary layer. Important gasphase products of fuel combustion from shipping are nitrogen oxides $\left(\mathrm{NO}_{\mathrm{x}}=\mathrm{NO}+\mathrm{NO}_{2}\right) . \mathrm{NO}_{\mathrm{x}}$ emissions lead to photochemical production of ozone $\left(\mathrm{O}_{3}\right)$ and influence the hydroxyl-radical $(\mathrm{OH})$ concentrations that determine the lifetime of methane $\left(\mathrm{CH}_{4}\right)$ (Lawrence and Crutzen, 1999), both significant contributors to global radiative forcing (IPCC, 2007). Furthermore, high $\mathrm{O}_{3}$ mixing ratios in the lower troposphere are a key component of photochemical smog and pose a threat to human health and vegetation. Approximately $70 \%$ of ship emissions are estimated to occur within $400 \mathrm{~km}$ of land (Corbett et al., 1999), so ships contribute significantly to pollution in highly populated coastal areas.

Ships are strong polluters because they are still allowed to combust marine heavy fuel. Marine engines combust this fuel at high temperatures, leading to relatively high $\mathrm{NO}_{\mathrm{x}}$ emissions. No international legislative framework is currently in place for monitoring and allocating international

Published by Copernicus Publications on behalf of the European Geosciences Union. 
ship emissions. Only recently, the European Union and the United States Environmental Protection Agency (EPA) issued the mandatory use of cleaner shipping fuel types in the increasingly polluted harbour regions. Previous studies (e.g. Corbett et al., 2007; Eyring et al., 2010) indicate that the total $\mathrm{NO}_{\mathrm{x}}$ emissions from shipping are in the range $3.0-10.4 \mathrm{Tg} \mathrm{N}$ per year, amounting to $15-30 \%$ of total global $\mathrm{NO}_{\mathrm{x}}$ emissions.

State-of-science knowledge of the impact of ship emissions relies on emissions inventories in combination with model studies (e.g. Corbett et al., 1999; Eyring et al., 2005; Wang et al., 2008; Marmer et al., 2009). Standard Eulerian chemistry-transport models (CTMs) simulate atmospheric concentrations of air pollutants by instant dilution of highly localised sources (e.g. power plants, highways) over the entire model grid cell. This is an acceptable simplification for chemically inert species, and probably also for chemically reactive species, provided that there are many such sources within a model cell. However, when emitting chemically reactive species from highly localised sources in relatively clean areas (e.g. ship stacks), instant dilution leads to unrealistically high $\mathrm{NO}_{\mathrm{x}}$ and $\mathrm{O}_{3}$ concentrations (Davis et al., 2001). Such overestimations occur because non-linear chemistry during the initial dispersion stage of the plume is neglected in the instant dilution approach. For example, Kasibhatla et al. (2000) found that their instantly diluting model $\left(\mathrm{GFDL}, 5^{\circ} \times 5^{\circ}\right)$ simulated $\mathrm{NO}_{\mathrm{x}}$ concentrations that were $10 \times$ higher than observations over the central North Atlantic. Franke et al. (2008) reported that instant dilution of ship $\mathrm{NO}_{\mathrm{x}}$ emissions in a grid box comparable to the grid cell size of a global model $\left(2.8^{\circ} \times 2.8^{\circ}\right)$ leads to overestimation of shipinduced ozone production by a factor three. A recent study by Charlton-Perez et al. (2009) suggests, by comparing simulations at different resolutions from a high resolution CTM $(200 \mathrm{~m} \times 200 \mathrm{~m} \times 40 \mathrm{~m})$, that a coarse-grid CTM $\left(5^{\circ} \times 5^{\circ}\right)$ might overestimate $\mathrm{O}_{3}$ production by a factor of 1.6. Several studies with Lagrangian models (e.g. von Glasow et al., 2003; Song et al., 2003; Chen et al., 2005) showed that the $\mathrm{NO}_{\mathrm{x}}$ lifetime within ship plumes is a factor 2.5-10 shorter than the lifetime of roughly 1 day estimated by the instantly diluting CTMs. These Lagrangian models account for the higher $\mathrm{NO}_{\mathrm{x}}$ concentrations in the initial dispersion stages of the plume, leading to elevated $\mathrm{OH}$ levels and thereby shorter $\mathrm{NO}_{\mathrm{x}}$ lifetimes.

Not a single global CTM currently uses a realistic physical and chemical model of non-linear chemistry during ship plume dispersion to account for in-plume effects. Both the GEOS-Chem (Bey et al., 2001) and GMI model (as in Duncan et al. (2008)) use an empirical correction. However, that correction is based on ozone production observed during one single measurement campaign (Chen et al., 2005), and does not account for the dependency of this ozone production on environmental parameters. Most models use instant dilution to mix ship emissions with background concentrations of trace gases. The GEOS-Chem model attempts to avoid model errors associated with instant dilution by replacing every emitted $\mathrm{NO}_{\mathrm{x}}$ molecule by $10 \mathrm{O}_{3}$ and $1 \mathrm{HNO}_{3}$ molecules, based on the average ozone production efficiency of $10 \mathrm{CO}_{3}$ molecules produced per $\mathrm{NO}_{\mathrm{x}}$ molecule consumed) observed over the eastern Pacific Ocean near California (Chen et al., 2005). Although this approach appears to overcome some of the model errors encountered by other CTMs, it erroneously produces $\mathrm{O}_{3}$ at night, neglects effects of temperature and ambient concentrations on $\mathrm{O}_{3}-\mathrm{NO}_{\mathrm{x}}$ chemistry, and underestimates $\mathrm{NO}_{\mathrm{x}}$ concentrations in shipping routes, making it practically impossible to use the model in combination with in situ or satellite observations of $\mathrm{NO}_{\mathrm{x}}$ to constrain ship $\mathrm{NO}_{\mathrm{x}}$ emissions. The Global Modeling Initiative's (GMI) tropospheric CTM used by Duncan et al. (2008) corrects for the continuous $\mathrm{O}_{3}$ production at night by scaling the ozone production efficiency with the $\mathrm{NO}_{2}$ photolysis rate, but does not account for either the effects of temperature or ambient concentrations of especially $\mathrm{NO}_{\mathrm{x}}$ or $\mathrm{O}_{3}$.

One way to accurately represent highly localised emissions in remote locations in coarse global models is by using the concept of "effective emissions". In this approach, a small-scale model is used to evaluate the effects of non-linear chemistry on the enhanced concentrations in a plume up until the moment that sub-grid chemical nonlinearities have sufficiently decayed, and subsequently introduce the emissions as (reduced) "effective emissions" in the large-scale model (in the past used for dealing with urban and power plant plume in Eulerian models, Sillman et al., 1990). Such an approach has been attempted for aircraft emissions in the TM3 global CTM (Meijer et al., 1997) and recently also for ship emissions in a regional model (Huszar et al., 2010) (using effective reaction rates). Huszar et al. (2010) found, using a regional CTM (CAMx) over Europe, that the large scale $\mathrm{NO}_{\mathrm{x}}$ concentrations decrease and the ship $\mathrm{NO}_{\mathrm{x}}$ contribution is reduced by up to 20-25\% (compared to instant dilution) and that the ship induced ozone production was reduced by $15-$ $30 \%$ over large areas of Europe.

In this study we propose a method to accurately implement ship emissions using a plume-in-grid approach, accounting for non-linear chemistry during the early stages of plume dispersion in the GEOS-Chem global CTM. We model the effects of non-linear chemistry within a ship exhaust plume with a Gaussian dispersion model that includes complete atmospheric chemistry. In situ observations of trace gases in ship plumes are used to test our Gaussian dispersion model. We test and evaluate various approaches of dealing with ship emissions in a global CTM with observations over the Atlantic and Pacific Ocean. 


\section{Model}

\subsection{PARANOX model}

In this study, a Gaussian dispersion plume model named PARANOX (PARAmetrization of emitted NOX) has been used. The basic characteristics of this model were described by Meijer (2001) and Vinken (2010). This model was originally designed to simulate the effects of aircraft emissions in the upper troposphere, but for this study we adapted it to marine boundary layer conditions. The model simulates the chemical evolution of atmospheric trace gas concentrations resulting from emissions in 10 rings perpendicular to the wind direction, as a cross-section of the plume. The model takes into account the chemistry inside and outside the plume, diffusion of emitted species inside the plume between the rings, expansion of the plume, and entrainment of ambient air into the plume. In this section we first describe the general characteristics of PARANOX and then evaluate PARANOX with ship plume observations from the ITCT 2002 aircraft campaign (Chen et al., 2005).

The model includes a detailed simulation of $\mathrm{O}_{3}-\mathrm{NO}_{\mathrm{x}}-$ hydrocarbon chemistry for the troposphere, with 43 species and 98 reactions. Originally the gas-phase reaction rates were taken from DeMore et al. (1997). We updated PARANOX with the latest reaction rates from the IUPAC Subcommittee for Gas Kinetic Data Evaluation (http://www. iupac-kinetic.ch.cam.ac.uk/index.html). Rainout of species is not taken into account. The time step in the model is $100 \mathrm{~s}$. To facilitate the discussion of plume chemistry in the remainder of the paper, the most critical $\mathrm{O}_{3}-\mathrm{NO}_{\mathrm{y}}-\mathrm{HO}_{\mathrm{x}}$ reactions for both day and nighttime are given in Table 1 .

Sulphate particles are formed in the ship plume, which allow heterogeneous reactions in the plume. The PARANOX model includes heterogeneous formation of $\mathrm{HNO}_{3}$ from $\mathrm{N}_{2} \mathrm{O}_{5}$ and $\mathrm{H}_{2} \mathrm{O}$ on aerosols. The reaction rate constant $K_{\text {het }}\left(\mathrm{s}^{-1}\right)$ of Reaction (R12) is given by

$K_{\text {het }}=\frac{1}{4} \gamma \nu S$.

With $\gamma$ the reaction probability, $S\left(\mathrm{~cm}^{-1}\right)$ is the aerosol surface area density, and $v\left(\mathrm{~cm} \mathrm{~s}^{-1}\right)$ is the mean absolute molecular velocity of air molecules. Originally the reaction probability of $\mathrm{N}_{2} \mathrm{O}_{5}$ on sulphate aerosol was 0.1 , as suggested for tropospheric conditions above $200 \mathrm{~K}$ by DeMore et al. (1997). Following recent studies, e.g. Evans and Jacob (2005), we updated this reaction probability to 0.02 .

In this study we follow an approach for the lateral and vertical dispersion in the lower troposphere originally described by Hanna et al. (1985) (Offshore and Coastal Dispersion algorithm), adapted for dispersion calculations over water by Song et al. (2003) and commonly used to describe ship plume dispersion (e.g. Franke et al., 2008; Kim et al., 2009; Song et al., 2010). These lateral and vertical dispersion parameters depend on the meteorological stability class and can be tuned
Table 1. Most critical $\mathrm{O}_{3} / \mathrm{NO}_{\mathrm{y}} / \mathrm{HO}_{\mathrm{x}}$ reactions in PARANOX for both day and nighttime. We use $R \mathrm{H}$ as simplified notation for Volatile Organic Compounds (VOCs) $(R$ represents an organic group).

\begin{tabular}{|c|c|}
\hline $\begin{array}{l}\text { (R1)* } \\
\text { (R2) } \\
\text { (R3) } \\
\text { (R4) }\end{array}$ & $\begin{array}{l}\mathrm{O}_{3}+h v+\mathrm{H}_{2} \mathrm{O} \rightarrow x_{1} \mathrm{OH}+x_{2} \mathrm{O}_{3}+\mathrm{O}_{2} \\
\mathrm{NO}_{2}+\mathrm{OH}+\mathrm{M} \rightarrow \mathrm{HNO}_{3}+\mathrm{M} \\
\mathrm{O}_{3}+\mathrm{NO} \rightarrow \mathrm{NO}_{2}+\mathrm{O}_{2} \\
\mathrm{NO}+\mathrm{HO}_{2} \rightarrow \mathrm{NO}_{2}+\mathrm{OH}\end{array}$ \\
\hline $\begin{array}{l}\text { (R5) } \\
\text { (R6) } \\
\text { (R7) }\end{array}$ & $\begin{array}{l}\mathrm{NO}_{2}+h v \stackrel{\mathrm{O}_{2}}{\longrightarrow} \mathrm{NO}+\mathrm{O}_{3} \\
\mathrm{O}_{3}+\mathrm{NO}_{2} \rightarrow \mathrm{NO}_{3}+\mathrm{O}_{2} \\
\mathrm{NO}_{2}+\mathrm{NO}_{3}+\mathrm{M} \rightarrow \mathrm{N}_{2} \mathrm{O}_{5}+\mathrm{M}\end{array}$ \\
\hline (R8) & $\mathrm{CH}_{4}+\mathrm{OH} \stackrel{\mathrm{O}_{2}}{\longrightarrow} \mathrm{CH}_{3} \mathrm{O}_{2}+\mathrm{H}_{2} \mathrm{O}$ \\
\hline (R9) & $\mathrm{CH}_{3} \mathrm{O}_{2}+\mathrm{NO} \stackrel{\mathrm{O}_{2}}{\longrightarrow} \mathrm{HCHO}+\mathrm{HO}_{2}+\mathrm{NO}_{2}$ \\
\hline (R10) & $\mathrm{CO}+\mathrm{OH} \stackrel{\mathrm{O}_{2}}{\longrightarrow} \mathrm{HO}_{2}+\mathrm{CO}_{2}$ \\
\hline (R11) & $\mathrm{NO}_{3}+h v \stackrel{\mathrm{O}_{2}}{\longrightarrow} \mathrm{NO}_{2}+\mathrm{O}_{3}$ \\
\hline (R12) & $\mathrm{N}_{2} \mathrm{O}_{5}+\mathrm{H}_{2} \mathrm{O} \stackrel{\text { aer. }}{\longrightarrow} 2 \mathrm{HNO}_{3}$ \\
\hline (R13) & $R \mathrm{H}+\mathrm{OH} \stackrel{\mathrm{O}_{2}}{\longrightarrow} R \mathrm{O}_{2}+\mathrm{H}_{2} \mathrm{O}$ \\
\hline (R14) & $R \mathrm{O}_{2}+\mathrm{NO} \rightarrow R \mathrm{O}+\mathrm{NO}_{2}$ \\
\hline
\end{tabular}

* This reaction is a net reaction of the loss of $\mathrm{O}_{3}$ by photolysis to $\mathrm{O}\left({ }^{1} \mathrm{D}\right)$, followed by three possible reactions. The $\mathrm{O}\left({ }^{1} \mathrm{D}\right)$ can react with $\mathrm{H}_{2} \mathrm{O}$ forming $2 \mathrm{OH}$ molecules, the $\mathrm{O}\left({ }^{1} \mathrm{D}\right)$ can react with $\mathrm{N}_{2}$ forming $\mathrm{O}\left({ }^{3} \mathrm{P}\right)$ and $\mathrm{N}_{2}$ or the $\mathrm{O}\left({ }^{1} \mathrm{D}\right)$ can react with $\mathrm{O}_{2}$ forming $\mathrm{O}\left({ }^{3} \mathrm{P}\right)$ and $\mathrm{O}_{2}$. From these last two possibilities, the $\mathrm{O}\left({ }^{3} \mathrm{P}\right)$ can react with $\mathrm{O}_{2}$ producing $\mathrm{O}_{3}$. In Reaction (R1) $x_{1}$ and $x_{2}$ are stochiometric coefficients, quantifying the relationship of reactants and products in this net reaction $\left(x_{1}+x_{2}=1\right)$. These stochiometric coefficients are calculated in PARANOX and depend on temperature, air density and $\mathrm{H}_{2} \mathrm{O}$ concentrations.

in PARANOX. The marine boundary layer is often topped by an inversion. It is generally assumed that plumes will not expand above this top. Therefore, we stop expansion in the vertical direction when the outer radius of the 10th ring reaches this top. After this top has been reached, the expansion in the lateral direction still continues.

\subsection{Evaluation of PARANOX}

In order to validate the simulations by the plume model, we compare our results with observations from the ITCT 2002 aircraft campaign (Chen et al., 2005). In this study, measurements were taken from a ship plume $100 \mathrm{~km}$ off the Californian coast around noon on 8 May 2002. Measurements of chemical species concentrations were taken at $\sim 100 \mathrm{~m}$ above sea level in eight consecutive transects of the ship plumes, corresponding to plume ages of $30 \mathrm{~min}$ up to $3 \mathrm{~h}$. Concentrations of $\mathrm{NO}_{\mathrm{x}}, \mathrm{HNO}_{3}, \mathrm{PAN}, \mathrm{SO}_{2}, \mathrm{H}_{2} \mathrm{SO}_{4}, \mathrm{O}_{3}, \mathrm{CO}$ and $\mathrm{CO}_{2}$ have been measured.

For the PARANOX evaluation we used a $\mathrm{NO}_{\mathrm{x}}$ emissions rate of $12.4 \mathrm{~g} \mathrm{~s}^{-1}$, as reported for the ITCT 2002 aircraft campaign by Chen et al. (2005). We adopt background concentrations as given in Table 2, consistent with the values reported for the ITCT 2002 aircraft campaign. 

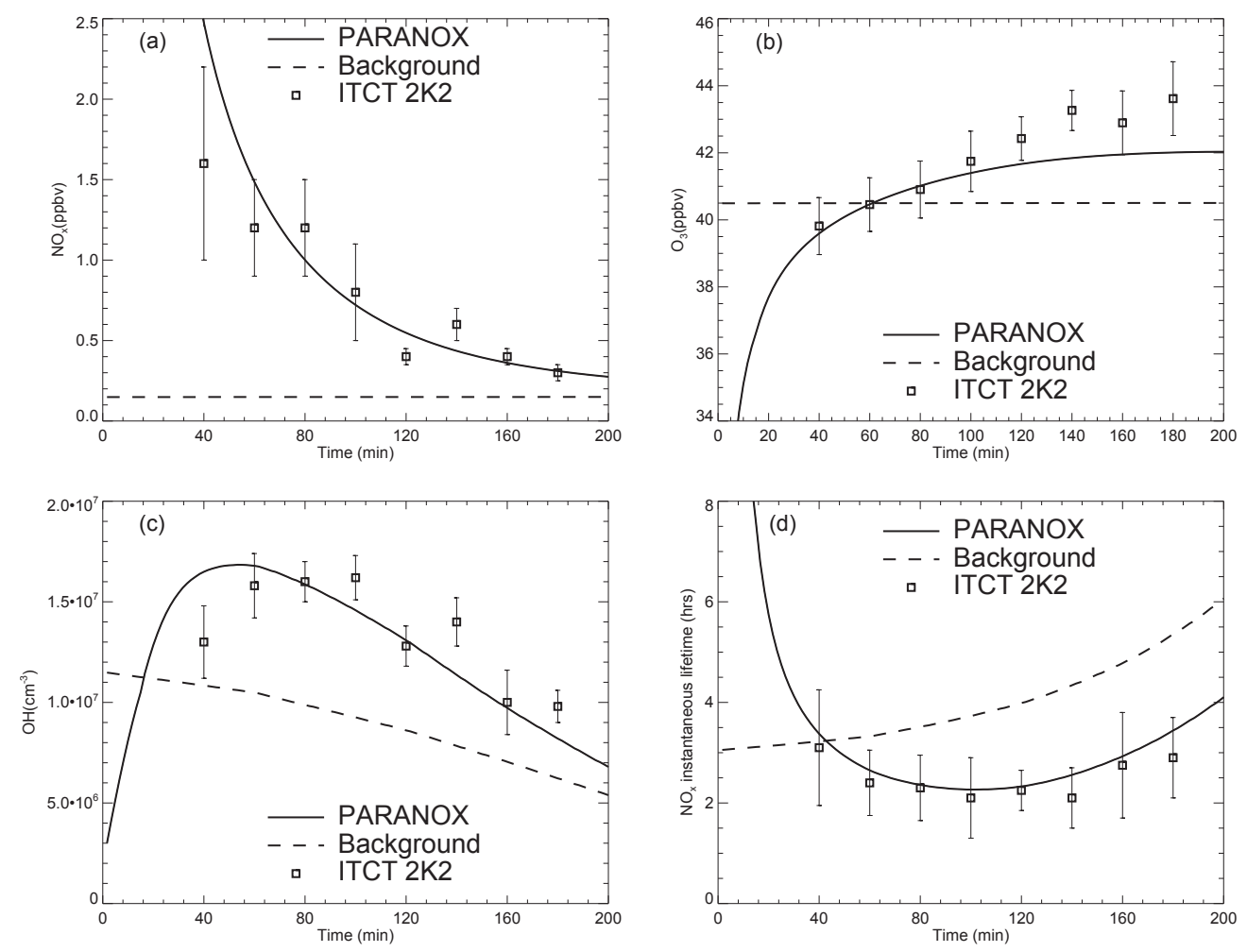

Fig. 1. Observed and simulated concentrations averaged over the cross-section of a ship plume released at 12:00 h local time as function of time since release for the species: (a) $\mathrm{NO}_{\mathrm{x}}$; (b) $\mathrm{O}_{3}$; (c) $\mathrm{OH}$ and (d) the $\mathrm{NO}_{\mathrm{x}}$ instantaneous lifetime as function of time. The solid line indicates the PARANOX simulation with ambient concentrations given in Table 2. The dashed line represents the background concentration and the squares represent the observations taken during the ITCT 2002 aircraft campaign on 8 May 2002, with the bars indicating measurement errors. The $\mathrm{OH}$ concentrations in (c) were inferred from $\mathrm{H}_{2} \mathrm{SO}_{4}$ measurements (Chen et al., 2005). The $\mathrm{NO}_{\mathrm{x}}$ instantaneous lifetime was calculated as the $\mathrm{NO}_{\mathrm{x}}$ concentration divided by the production rate of $\mathrm{HNO}_{3}$ at any point in time.

Table 2. Ambient concentrations used in the PARANOX simulation for comparison with ITCT 2002 observations (Chen et al., 2005)*

\begin{tabular}{lcccccccc}
\hline Species & $\mathrm{O}_{3}$ & $\mathrm{NO}_{\mathrm{x}}$ & $\mathrm{HNO}_{3}$ & $\mathrm{CO}$ & $\mathrm{SO}_{2}$ & $\mathrm{PAN}$ & $\mathrm{CH}_{3} \mathrm{CHO}$ & $\mathrm{CH}_{3} \mathrm{OH}$ \\
\hline $\begin{array}{l}\text { Ambient } \\
\text { Concentration (ppbv) }\end{array}$ & 40.5 & 0.150 & 0.005 & 130 & 0.4 & 0.16 & 0.1 & 0.25 \\
\hline
\end{tabular}

* During the measurements the wind speed was between 9 and $11 \mathrm{~m} \mathrm{~s}^{-1}$, in this comparison we set the wind speed to $10 \mathrm{~m} \mathrm{~s}{ }^{-1}$. The height of the marine boundary layer determined from aircraft measurements was $350 \mathrm{~m}$. The ambient temperature was $290 \mathrm{~K}$. We set the stability class to "moderately stable", following a recent study by Kim et al. (2009).

Figure 1 shows the evolution of observed and simulated $\mathrm{NO}_{\mathrm{x}}, \mathrm{O}_{3}$ and $\mathrm{OH}$ concentrations, as well as the instantaneous $\mathrm{NO}_{\mathrm{x}}$ lifetime, in the plume during the $3 \mathrm{~h}$ after emissions. The PARANOX simulated concentrations correspond to the weighted average over the 10 rings.

To structure the discussion of the results, we separate the plume dispersion in three regimes, as proposed by Song et al. (2003): early plume dispersion ([ $\left.\mathrm{NO}_{\mathrm{x}}\right]$ above $\left.1 \mathrm{ppmv}\right)$, midrange dispersion $\left(\left[\mathrm{NO}_{\mathrm{x}}\right] \sim\right.$ several ppbv), and long-range dispersion $\left(\left[\mathrm{NO}_{\mathrm{x}}\right]\right.$ below $\left.1 \mathrm{ppbv}\right)$. We can also classify the evolution of the plume by following the $\mathrm{O}_{3}$ concentrations: $\mathrm{O}_{3}$ titration ( $\left[\mathrm{O}_{3}\right]$ less than half of ambient concentration), $\mathrm{O}_{3}$ recovery ( $\left[\mathrm{O}_{3}\right]$ increasing to ambient concentration), and net $\mathrm{O}_{3}$ production $\left(\left[\mathrm{O}_{3}\right]\right.$ above ambient concentration).

The strong decline in the $\mathrm{O}_{3}$ concentrations during the first stage is caused by the $\mathrm{O}_{3}$ being titrated by the abundantly available $\mathrm{NO}$ via Reaction (R3). Almost all $\mathrm{O}_{3}$ within the plume is gone at this point, but stored as $\mathrm{NO}_{2}$ and will later be recycled. In the second stage, $\mathrm{HO}_{2}$ is converted to $\mathrm{OH}$ and $\mathrm{NO}_{2}$ via Reaction (R4) (this is reflected by the rise in $\mathrm{OH}$ concentrations in Fig. 1c). The $\mathrm{NO}_{2}$ is then photolyzed (Reaction $\mathrm{R} 5$ ), leading to net photochemical $\mathrm{O}_{3}$ production (Fig. 1b). The $\mathrm{OH}$ concentrations are maximal in this stage and almost 2 times higher than background levels. These 
high $\mathrm{OH}$ concentrations imply a shorter $\mathrm{NO}_{\mathrm{x}}$ lifetime and a relatively low fraction of $\mathrm{NO}_{\mathrm{x}}$ remaining. By instantly diluting the emissions, common practice in global CTMs, this stage is missing and this results in too high $\mathrm{NO}_{\mathrm{x}}$ lifetimes. After about $80 \mathrm{~min}$ the final stage sets in. Reactions of $\mathrm{NO}$ with $\mathrm{HO}_{2}$ (Reaction $\left.\mathrm{R} 4\right)$ and organic peroxides (e.g. $\mathrm{CH}_{3} \mathrm{O}_{2}$, Reaction R9) lead to increasing levels of photochemically produced $\mathrm{O}_{3}$, as shown in Fig. 1b. All three stages show that PARANOX simulations agree with the observed concentrations.

As mentioned before, the main problem in global CTMs is the overestimation of the lifetime of ship emitted $\mathrm{NO}_{\mathrm{x}}$ due to instant dilution. In this study we define the $\mathrm{NO}_{\mathrm{x}}$ lifetime within the plume in terms of how fast $\mathrm{NO}_{\mathrm{x}}$ is lost at a given point in time, the so-called "instantaneous lifetime":

$\tau_{\mathrm{NO}_{\mathrm{x}}}=\frac{[\mathrm{NO}]+\left[\mathrm{NO}_{2}\right]}{P_{\mathrm{HNO}_{3}}}$.

The main sink of $\mathrm{NO}_{\mathrm{x}}$ during the day is reaction of $\mathrm{NO}_{2}$ with $\mathrm{OH}$ via Reaction (R2), i.e. the production of $\mathrm{HNO}_{3}$. At night it is mainly controlled by Reactions (R6) and (R7), which involve the formation of $\mathrm{NO}_{3}$ and $\mathrm{N}_{2} \mathrm{O}_{5}$, followed by $\mathrm{HNO}_{3}$ formation from $\mathrm{N}_{2} \mathrm{O}_{5}$ on sulphate aerosols (Reaction R12).

Figure $1 \mathrm{~d}$ shows that both the observed and simulated $\mathrm{NO}_{\mathrm{x}}$ lifetime in the plume are lower than the background lifetime. We conclude that the PARANOX model is able to capture the non-linear chemistry occurring in a dispersive ship plume, and we will now use it to account for these effects in the global CTM GEOS-Chem.

\section{Using PARANOX to account for non-linear plume chemistry}

As running PARANOX online for every ship plume would be computationally too expensive, the PARANOX model is used to calculate look-up tables (LUTs) to account for the non-linear chemistry in a dispersive ship plume in the global CTM. First, we perform a sensitivity analysis to determine the critical (environmental) parameters that need to be included in the LUT. Once the most critical dependencies are known, we can calculate LUTs for the fraction of $\mathrm{NO}_{\mathrm{x}}$ remaining and integrated net ozone production efficiency (NOPE). In these LUTs we save the fraction of $\mathrm{NO}_{\mathrm{x}}$ remaining and the integrated NOPE as a function of critical environmental parameters at the end of the PARANOX simulation, which we set at $5 \mathrm{~h}$ (see discussion in Sect. 3.3). Values for the environmental parameters are taken from GEOS-Chem simulations at the location and time of the ship emissions.

\subsection{Fraction of $\mathrm{NO}_{\mathrm{x}}$ remaining and integrated NOPE}

We apply PARANOX to simulate the in-plume effects for various environmental conditions, and calculate the fraction of $\mathrm{NO}_{\mathrm{x}}$ remaining and the integrated NOPE. The fraction of
$\mathrm{NO}_{\mathrm{x}}$ remaining is determined by dividing the mass of the emitted $\mathrm{NO}_{\mathrm{x}}$, chemically evolved to $\mathrm{NO}, \mathrm{NO}_{2}, \mathrm{NO}_{3}, \mathrm{~N}_{2} \mathrm{O}_{5}$, $\mathrm{HONO}, \mathrm{HO}_{2} \mathrm{NO}_{2}$ or PAN (excluding $\mathrm{HNO}_{3}$ ), in the plume at time $t$ by the mass of emitted $\mathrm{NO}_{\mathrm{x}}$ in the plume at time $t=0$. The fraction of $\mathrm{NO}_{\mathrm{x}}$ remaining will be used to reduce the amount of $\mathrm{NO}_{\mathrm{x}}$ upon release at time $t$ in the global CTM with the coarse spatial resolution.

An important concept in $\mathrm{O}_{3}$ production by $\mathrm{NO}_{\mathrm{x}}$ emissions is the Net Ozone Production Efficiency (NOPE). The NOPE $(\omega)$ is defined as the cross-plume integral of net number of ozone molecules produced divided by the cross-plume integral of ship emitted $\mathrm{NO}_{\mathrm{x}}$ consumed at any point in time. In PARANOX, we label the emitted $\mathrm{NO}_{\mathrm{x}}$ molecules so that we can distinguish between $\mathrm{O}_{3}$ molecules produced (or lost) from ship $\mathrm{NO}_{\mathrm{x}}$ and $\mathrm{O}_{3}$ molecules produced from in-plume entrainment of ambient $\mathrm{NO}_{\mathrm{x}}$. In this study we take the loss of $\mathrm{NO}_{\mathrm{x}}$ to be equal to the production of $\mathrm{HNO}_{3}$, leading to

$\omega=\frac{P_{\mathrm{O}_{3}}-L_{\mathrm{O}_{3}}}{P_{\mathrm{HNO}_{3}}}$.

$\mathrm{HNO}_{3}$ is the main sink for $\mathrm{NO}_{\mathrm{x}}$ and is removed by deposition. PARANOX does not take deposition into account, but the global CTM eventually solves removal by deposition, as we will see in Sect. 4.

The NOPE described above should be regarded as an "instantaneous NOPE". When using the ship plume model as a pre-processor to calculate effective ship emissions, we need to assess the NOPE during the entire plume expansion. For this reason we introduce the "integrated NOPE". This integrated NOPE $(\Omega)$ is determined by the ratio of the total net ozone produced (by the ship emitted $\mathrm{NO}_{\mathrm{x}}$ ) and the total (ship emitted) $\mathrm{NO}_{\mathrm{x}}$ lost $\left(\mathrm{HNO}_{3}\right.$ produced), integrated over all rings, between $t^{\prime}=0$ and $t$ :

$\Omega=\frac{\int_{t^{\prime}=0}^{t}\left\{P_{\mathrm{O}_{3}}-L_{\mathrm{O}_{3}}\right\} d t^{\prime}}{\int_{t^{\prime}=0}^{t} P_{\mathrm{HNO}_{3}} d t^{\prime}}$

in which $t$ is the end time of the model (order of several hours).

\subsection{Sensitivity analysis}

The fraction of $\mathrm{NO}_{\mathrm{x}}$ remaining and the integrated NOPE depend on atmospheric composition and meteorological conditions. Before calculating the fraction of $\mathrm{NO}_{\mathrm{x}}$ remaining and integrated NOPE for our look-up tables, we identified the dependencies that have the strongest influence. We study the sensitivity of the fraction of $\mathrm{NO}_{\mathrm{x}}$ remaining and the integrated NOPE to the following environmental parameters: ambient temperature, wind speed, $\left[\mathrm{O}_{3}\right],[\mathrm{CO}],\left[\mathrm{NO}_{\mathrm{X}}\right]$, solar zenith angle at time of release, solar zenith angle after $5 \mathrm{~h}, J\left(\mathrm{NO}_{2}\right)$ (the photolysis rate constant for $\left.\mathrm{NO}_{2}\right), \frac{\left.J\left(\mathrm{O}^{1} \mathrm{D}\right)\right)}{J\left(\mathrm{NO}_{2}\right)}$, marine boundary layer (MBL) height, and $\mathrm{NO}_{\mathrm{x}}$ emission strength. 
Table 3. Summary of $\mathrm{NO}_{\mathrm{x}}$ ship emissions strengths currently used in literature.

\begin{tabular}{lr}
\hline Study & $\begin{array}{r}\mathrm{NO}_{\mathrm{x}} \text { emission } \\
\text { strength }\left(\mathrm{g} \mathrm{s}^{-1}\right)\end{array}$ \\
\hline Charlton-Perez et al. (2009) & 33 \\
Franke et al. (2008) & $145^{\mathrm{a}}$ \\
Schlager et al. (2008) & $184^{\mathrm{a}}$ \\
Kim et al. (2009) & $6.25^{\mathrm{b}}$ \\
Chen et al. (2005) & 13.4 \\
Song et al. (2003) & $4-20$ \\
von Glasow et al. (2003) & 19.1 \\
Eyring et al. (2005) & $9.31^{\mathrm{c}}$ \\
This study & 20 \\
\hline
\end{tabular}

a The emission strengths reported by Franke et al. (2008) and Schlager et al. (2008) hold for "fairly large container ships". b Based on Chen et al. (2005). c Calculated using annual emissions of cargo ships.

We choose to include $J\left(\mathrm{NO}_{2}\right)$ as a measure of visible radiation. The ratio $\frac{J\left(\mathrm{O}\left({ }^{1} \mathrm{D}\right)\right)}{J\left(\mathrm{NO}_{2}\right)}$ accounts for the overhead $\mathrm{O}_{3}$ column, as $J\left(\mathrm{O}\left({ }^{1} \mathrm{D}\right)\right)$ is a measure for UV radiation. Because ambient $\mathrm{NO}_{\mathrm{x}}$ concentrations are important in the efficiency of $\mathrm{NO}_{\mathrm{x}}$ destruction and $\mathrm{O}_{3}$ production, and ship lanes are located in pristine as well as heavy polluted areas, we include ambient $\mathrm{NO}_{\mathrm{x}}$ concentrations in the sensitivity study. We include ambient $\mathrm{CO}$ concentrations as available $\mathrm{CO}$ fuels $\mathrm{O}_{3}$ formation via Reactions R10-R4-R5. We use the solar zenith angle at the beginning and the end of the run to simulate the change in the photolysis values in the $5 \mathrm{~h}$ runtime.

Our sensitivity analysis pointed out that the fraction of $\mathrm{NO}_{\mathrm{x}}$ remaining and integrated NOPE were relatively insensitive to changes in the wind speed, marine boundary layer height and emissions. However, a combination of low wind speed, low marine boundary layer height, and high emissions is important in causing a saturation effect. This effect causes the fraction of $\mathrm{NO}_{\mathrm{x}}$ to increase with decreasing wind speeds, with decreasing marine boundary layer heights and with increasing emissions. If such situations occur frequently in GEOS-Chem, it would be important to include these dependencies in the LUT. In this study we adopt a relatively modest $\mathrm{NO}_{\mathrm{x}}$ emission strength of $20 \mathrm{~g} \mathrm{~s}^{-1}$, in line with current estimates used in literature (Table 3 ). The fluxes at the high end of the distribution, reported by Franke et al. (2008) and Schlager et al. (2008), hold for "fairly large container ships", which is unlikely to represent the global fleet average emission strength. Furthermore, we analysed the ensemble of GEOS-Chem simulations and concluded that low wind speed events combined with a thin MBL occur infrequently (less than $4 \%$ ). This led us - in combination with modest $\mathrm{NO}_{\mathrm{x}}$ emission strength of $20 \mathrm{~g} \mathrm{~s}^{-1}$ - to decide to not include wind speed and MBL height in the LUT. Furthermore, we do not include ambient CO concentration in the LUT, as we found that the effect of changing ambient $\mathrm{CO}$ concentrations on the fraction of $\mathrm{NO}_{\mathrm{x}}$ remaining and the integrated NOPE is only small.

Figure 2 shows the fraction of $\mathrm{NO}_{\mathrm{x}}$ remaining after $5 \mathrm{~h}$ as a function of the most important environmental parameters for an initial release at 12:00 h local time. Higher temperatures lead to lower fractions of $\mathrm{NO}_{\mathrm{x}}$ remaining, as shown in Fig. 2a. Figure $2 b$ shows that the fraction of $\mathrm{NO}_{\mathrm{x}}$ remaining decreases with increasing $\mathrm{O}_{3}$ concentrations, because these favour $\mathrm{OH}$ formation (via Reaction $\mathrm{R} 1$ ), which in turn lowers the $\mathrm{NO}_{\mathrm{x}}$ lifetime. For increasing ambient $\mathrm{NO}_{\mathrm{x}}$ concentrations, the fraction of (ship) $\mathrm{NO}_{\mathrm{x}}$ remaining initially decreases (Fig. 2c). For ambient concentrations above 1-2 ppbv, the fraction of $\mathrm{NO}_{\mathrm{x}}$ remaining increases as $\mathrm{O}_{3}$ is titrated and $\mathrm{OH}$ concentrations decrease. Figure $2 \mathrm{~d}$ shows that higher values of $J\left(\mathrm{NO}_{2}\right)$, lead to lower fractions of $\mathrm{NO}_{\mathrm{x}}$ remaining. Higher values of $J\left(\mathrm{NO}_{2}\right)$ represent more sunlight and a more photochemically active regime, leading to lower $\mathrm{NO}_{\mathrm{x}}$ lifetimes. Figure $2 \mathrm{e}$ shows that the fraction of $\mathrm{NO}_{\mathrm{x}}$ remaining decreases with $\frac{J\left(\mathrm{O}\left({ }^{1} \mathrm{D}\right)\right)}{J\left(\mathrm{NO}_{2}\right)}$, reflecting an increase in $\mathrm{OH}$ produced via Reaction (R1). The solar zenith angle at the time of emission $\left(\theta_{0}\right)$ is an important parameter in determining the fraction of $\mathrm{NO}_{\mathrm{x}}$ remaining, as illustrated by Fig. 2f. For a value of $\theta_{0}=10^{\circ}$ (noon at low latitudes), the plume started expanding at a time when the sun was high and photolysis was strong, leading to a short instantaneous $\mathrm{NO}_{\mathrm{x}}$ lifetime, as reflected by the low fraction of $\mathrm{NO}_{\mathrm{x}}$ remaining. The apparent jump in the fraction of $\mathrm{NO}_{\mathrm{x}}$ remaining at $\theta_{0}=90^{\circ}$ marks the difference between a plume that expanded in darkness and a plume that expanded in sunlight for $5 \mathrm{~h}$. Figure $2 \mathrm{~g}$ shows that the fraction of $\mathrm{NO}_{\mathrm{x}}$ remaining also depends on the solar zenith angle $5 \mathrm{~h}$ after release $\left(\theta_{5}\right)$, and the effect is similar to the sensitivity to $\theta_{0}$.

Figure 3 shows the integrated NOPE after $5 \mathrm{~h}$ as a function of the most important environmental parameters for an initial release at 12:00 p.m. Figure 3a shows the sensitivity of the integrated NOPE to temperature, and can be explained by the subsequent changes in $\mathrm{H}_{2} \mathrm{O}$ concentrations. The integrated NOPE decreases strongly with increasing background $\mathrm{O}_{3}$ concentrations, as is shown in Fig. 3b. Additional simulations show that this is due to a combination of lower $\mathrm{O}_{3}$ production, higher $\mathrm{O}_{3}$ loss and increased $\mathrm{NO}_{\mathrm{x}}$ loss, as in Fig. 2b. Figure $3 \mathrm{c}$ indicates that for higher $\mathrm{NO}_{\mathrm{x}}$ concentrations, $\mathrm{O}_{3}$ production becomes less efficient. When ambient $\mathrm{NO}_{\mathrm{x}}$ concentrations exceed 2 ppbv, $\mathrm{O}_{3}$ loss (via titration) exceeds $\mathrm{O}_{3}$ production and the NOPE may become negative. In Fig. 3d, we see that the integrated NOPE increases as a function of $J\left(\mathrm{NO}_{2}\right)$, as high values of $J\left(\mathrm{NO}_{2}\right)$ increase photochemical ozone production via Reaction (R5). The NOPE decreases for increasing $\frac{J\left(\mathrm{O}\left({ }^{1} \mathrm{D}\right)\right)}{J\left(\mathrm{NO}_{2}\right)}$ ratios, reflecting enhanced photolysis loss through Reaction (R1), as illustrated by Fig. 3e. As expected, the solar zenith angles are important parameters for the integrated NOPE. For example, in Fig. 3f, $\theta_{0}=10^{\circ} \mathrm{im}-$ plies a strong integrated NOPE. In contrast, when the plume expansion started at night $\left(\theta_{0}>90\right)$, the integrated NOPE 

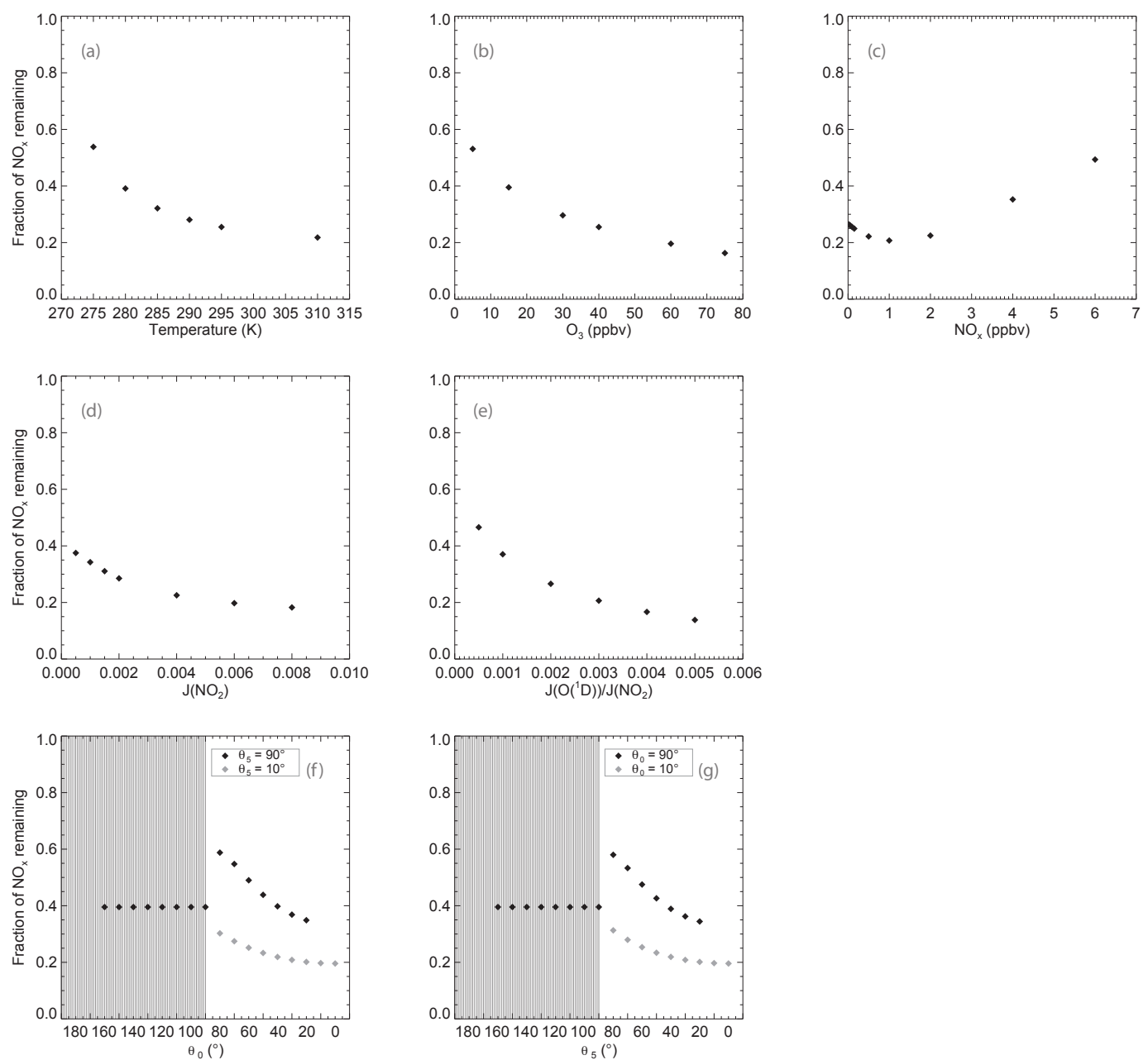

Fig. 2. PARANOX simulations of the fraction of $\mathrm{NO}_{\mathrm{x}}$ remaining after 5 hours for a plume released at 12:00 $\mathrm{h}$ local time as a function of: (a) Temperature; (b) ambient $\mathrm{O}_{3}$ concentration; (c) ambient $\mathrm{NO}_{\mathrm{x}}$ concentration; (d) $J\left(\mathrm{NO}_{2}\right) ;(\mathbf{e}) \frac{J\left(\mathrm{NO}_{2}\right)}{\mathrm{J}\left(\mathrm{O}\left({ }^{1} \mathrm{D}\right)\right)} ;(\mathbf{f}) \theta_{0}$ and $(\mathbf{g}) \theta_{5} . \theta_{0}$ and $\theta_{5}$ are the solar zenith angle at initial release and $5 \mathrm{~h}$ later. The simulation in panel (f) and (g) were not released at 12:00 h, but for different initial and final solar zenith angles, corresponding to a variety of release hours at different latitudes. The shaded areas in panel (f) and (g) correspond to simulations during darkness. A NO $\mathrm{x}_{\mathrm{x}}$ emissions strength of $20 \mathrm{~g} \mathrm{~s}^{-1}$ has been used. Ambient meteorological conditions are a neutral stability class, wind velocity is taken to be $8 \mathrm{~m} \mathrm{~s}^{-1}$, temperature $295 \mathrm{~K}$ and marine boundary layer height $400 \mathrm{~m}$. Ambient concentrations for $\mathrm{O}_{3}$ and $\mathrm{NO}_{\mathrm{x}}$ were set to $40 \mathrm{ppbv}$ and $100 \mathrm{pptv}$, respectively.

is negative, reflecting $\mathrm{O}_{3}$ loss. The sensitivity of the integrated NOPE to the solar zenith angle $5 \mathrm{~h}$ after release $\left(\theta_{5}\right)$ differs more from that of $\theta_{0}$ than for the fraction of $\mathrm{NO}_{\mathrm{x}}$ remaining. If the plume was in daylight at the end of the $5 \mathrm{~h}$, the $\mathrm{NO}_{\mathrm{x}}$ concentrations are lower due to expansion and the plume is more efficient at producing ozone; hence, this leads to a higher integrated NOPE, as can be seen by comparing Fig. $3 \mathrm{f}$ and $\mathrm{g}$.

\subsection{Look-up table}

We proceed and calculate two look-up tables (LUTs), storing the fraction of $\mathrm{NO}_{\mathrm{x}}$ remaining and the integrated NOPE as a function of 7 parameters after $5 \mathrm{~h}$ : temperature, $J\left(\mathrm{NO}_{2}\right)$, $\frac{J\left(\mathrm{O}\left({ }^{1} \mathrm{D}\right)\right)}{J\left(\mathrm{NO}_{2}\right)}$, (ambient) $\mathrm{O}_{3}$ concentrations, (ambient) $\mathrm{NO}_{\mathrm{x}}$ concentrations, and the solar zenith angles at $t=0$ and $t=5 \mathrm{~h}$ These parameters were identified as the most relevant by the sensitivity analysis and Figs. 2 and 3.

The run time of PARANOX is an important parameter in the PARANOX model. Choosing it too short might lead to a too high fraction of $\mathrm{NO}_{\mathrm{x}}$ remaining and thus too much ozone production when diluted back into the global model. Choosing it too long exposes our simulations to transport of the plume-in-grid outside of the grid cell, especially for situations with strong winds. Another parameter influenced by the run time is the size of the plume. We chose $5 \mathrm{~h}$ in our runs, 

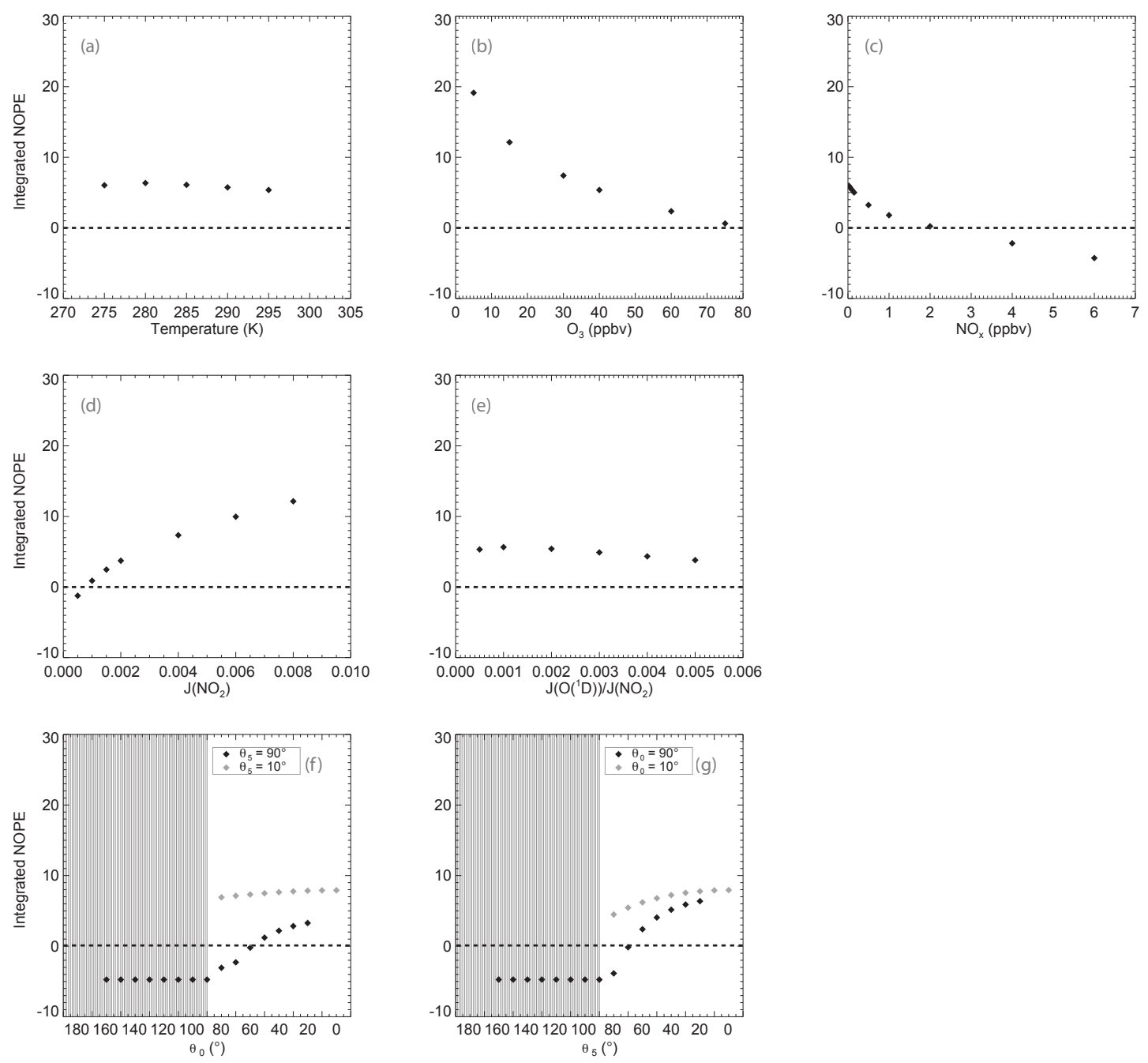

Fig. 3. PARANOX simulations of the integrated net ozone production efficiency (NOPE) after $5 \mathrm{~h}$ for a plume released at $12: 00 \mathrm{~h}$ local time as a function of: (a) temperature; (b) ambient $\mathrm{O}_{3}$ concentration; (c) ambient $\mathrm{NO}_{\mathrm{x}}$ concentration; (d) $J\left(\mathrm{NO}_{2}\right)$; (e) $\frac{J\left(\mathrm{NO}_{2}\right)}{J\left(\mathrm{O}\left({ }^{1} \mathrm{D}\right)\right)}$; (f) $\theta_{0}$ and $(\mathbf{g})$ $\theta_{5}$. The shaded areas in panel (f) and (g) correspond to simulations during darkness. Ambient meteorological conditions and concentrations as in Fig. 2.

as this will also allow the plumes to be well dispersed for higher mixing depths and the fast chemistry will generally have evolved within this timeframe (as shown in Fig. 1, enhanced background values occurred off the Californian coast in May 2002 within $3 \mathrm{~h}$ ).

In our method we assume that some of the environmental parameters do not change dramatically during the $5 \mathrm{~h}$ of plume dispersion $\left(J\left(\mathrm{O}\left({ }^{1} \mathrm{D}\right)\right)\right.$ and $J\left(\mathrm{NO}_{2}\right)$ follow changes in the solar zenith angle during the $5 \mathrm{~h}$ evolution). This introduces some errors in our method. Additional PARANOX situations show that a clouded sky from $t=1$ till $4 \mathrm{~h}$ (which in our method would be a cloud free run for $5 \mathrm{~h}$ ) results in an increase of $5 \%$ in the fraction of $\mathrm{NO}_{\mathrm{x}}$ remaining and a decrease of $5 \%$ in the integrated NOPE. A decrease in temperature (by $10 \mathrm{~K}$ ) during the last $2 \mathrm{~h}$ only leads to decreases less than $2 \%$. Reducing $\mathrm{NO}_{\mathrm{x}}$ concentrations for the first $3 \mathrm{~h}$ of plume dispersion (by $20 \%$ ) results in an increase in the fraction of $\mathrm{NO}_{\mathrm{x}}$ remaining of $2 \%$, and an increase in the integrated NOPE of $5 \%$. We conclude that our assumption of (some) constant environmental parameters during plume dispersion introduces errors in the fraction of $\mathrm{NO}_{\mathrm{x}}$ remaining and the integrated NOPE of at most $10 \%$, and that these errors largely cancel when temporal averages are analysed.

\section{Implementation and results}

In most CTMs, the ship emissions are instantly diluted in the grid cell, thereby neglecting the non-linear chemistry in the early stages of the exhaust plume. In our approach, we use the LUTs calculated by PARANOX, containing the fraction 
of $\mathrm{NO}_{\mathrm{x}}$ remaining and integrated NOPE, to account for the effects of plume dispersion and non-linear chemistry, by releasing reduced $\mathrm{NO}_{\mathrm{x}}$ emissions and net $\mathrm{O}_{3}$ and $\mathrm{HNO}_{3}$ produced into the large-scale global model.

\subsection{GEOS-Chem}

The chemistry transport model used in this study is GEOSChem version v8-03-02 (http://acmg.seas.harvard.edu/geos/) (Bey et al., 2001). We use GEOS-5 assimilated meteorological observations for the NASA Global Modeling and Assimilation Office (GMAO) to drive GEOS-Chem. The model has been run for tropospheric ozone- $\mathrm{NO}_{\mathrm{x}}-\mathrm{VOC}$-aerosol chemistry on a resolution of $2^{\circ} \times 2.5^{\circ}$, using a vertical grid containing 47 levels. The lowermost layer has a depth of $120 \mathrm{~m}$ and the vertical extent of the model is $80 \mathrm{~km}$.

We perform a spin-up of one year (2004) and run the actual simulations for the year 2005. Since version v8-01-04, ship emitted $\mathrm{NO}_{\mathrm{x}}$ molecules in GEOS-Chem are emitted as 1 molecule $\mathrm{HNO}_{3}$ and 10 molecules $\mathrm{O}_{3}$, based on the observations presented in Chen et al. (2005), to correct for the overproduction of $\mathrm{O}_{3}$ by instantly diluting the $\mathrm{NO}_{\mathrm{x}}$ emissions. We use the ICOADS global ship emissions inventory (Wang et al., 2008) and substitute this base inventory over Europe with the more detailed EMEP inventory (Vestreng et al., 2007). Neither inventory includes daily variation in the ship emissions, but the EMEP inventory includes seasonality.

\subsubsection{Adaptations to GEOS-Chem}

The sensitivity analysis showed that the fraction of $\mathrm{NO}_{\mathrm{x}}$ remaining and integrated NOPE critically depend on 7 environmental parameters: temperature, $J\left(\mathrm{NO}_{2}\right), \frac{J\left(\mathrm{O}\left({ }^{1} \mathrm{D}\right)\right)}{J\left(\mathrm{NO}_{2}\right)}$, (ambient) $\mathrm{O}_{3}$ concentrations, (ambient) $\mathrm{NO}_{\mathrm{x}}$ concentrations, and the solar zenith angles at $t=0$ and $t=5 \mathrm{~h}$. We obtain these values from the GEOS-Chem simulation at the model time. Based on these values we calculate the fraction of $\mathrm{NO}_{\mathrm{x}}$ remaining and the integrated NOPE (from linear interpolation between the closest reference values in the LUT). Both the calculated fraction of $\mathrm{NO}_{\mathrm{x}}$ remaining and the integrated NOPE are used to compute the reduction in $\mathrm{NO}_{\mathrm{x}}$ emissions and the amount of $\mathrm{O}_{3}$ and $\mathrm{HNO}_{3}$ produced. This is done to appropriately simulate the effects of original emissions that took place $5 \mathrm{~h}$ earlier and have been subject to nonlinear chemistry and dilution during the $5 \mathrm{~h}$ period. The changes in the photolysis values are modelled using the solar zenith angles, which are calculated at each model time step.

\subsubsection{Additional simulations}

For better understanding of the improved model and the effect of ship emissions, we adapted the GEOS-Chem model to run with instant dilution of the ship emitted $\mathrm{NO}_{\mathrm{x}}$ molecules, and we adapted the standard model to run without any ship emissions. The instant dilution model reflects how other global CTMs usually treat ship $\mathrm{NO}_{\mathrm{x}}$ emissions, while comparison with the model without ship emissions gives an indication of the effect of ship emissions on global atmospheric chemistry. We call the original model (v8-03-02, which releases every ship $\mathrm{NO}_{\mathrm{x}}$ molecule as 1 molecule $\mathrm{HNO}_{3}$ and 10 molecules $\mathrm{O}_{3}$ ) the standard model.

\subsection{Observations}

In order to test our adaptations and extensions to the model, we compare model simulations with measurements from dedicated campaigns performed over the Pacific and Atlantic Ocean. We used data from the Pacific Exploratory Mission-West-A (PEM-West A) (Hoell et al., 1996), the Pacific Exploratory Mission-West-B (PEM-West B) (Hoell et al., 1997), and North Atlantic Regional Experiment (NARE) (Ryerson et al., 1999) campaigns. PEM-West A was conducted over the North Pacific from 16 September till 21 October 1991, during a period of minimum outflow from Asia. PEM-West B was conducted from 7 February till 14 March 1994, during a period of enhanced outflow from Asia. NARE was conducted over the North Atlantic during September 1997.

From the PEM-West A and PEM-West B measurement campaigns, we used the $\mathrm{NO}$ and $\mathrm{O}_{3}$ measurements taken onboard a DC-8 aircraft. During PEM-West A and PEM-West $\mathrm{B}$, NO was recorded using the chemiluminescence technique (Kondo et al., 1996).

We regridded observations for each $2^{\circ} \times 2.5^{\circ}$ grid cell, using the median of the observations to suppress influence from outliers. In contrast with the in-plume measurements reported by Chen et al. (2005), the PEM-West A and PEMWest B measurements used here represent the marine background concentrations (influenced by ship emissions). Outliers in the PEM-West A and PEM-West B measurements could represent in-plume measurements and not the background concentrations.

For PEM-West A and PEM-West B, we limited the comparison with GEOS-Chem to grid boxes having observational data and being east of $145^{\circ} \mathrm{E}$. This presumably reduces the influence of outflow from anthropogenic sources in Asia. For NARE we limited the comparisons to a latitude and longitude range of $37-50^{\circ} \mathrm{N}$ and $35-50^{\circ} \mathrm{W}$, following Kasibhatla et al. (2000). This is also done to avoid the most intense continental outflow periods during this campaign. For all comparisons we compare average concentrations in the bottom 8 model levels ( 0 up to $1.2 \mathrm{~km}$ ) to the aircraft measurements below $1.2 \mathrm{~km}$.

\subsection{Comparison with observations}

Figure 4 shows Box \& Whisker plots of simulated and observed $\mathrm{NO}_{\mathrm{x}}$ concentrations in the marine boundary layer for the PEM-West B, PEM-West A and NARE campaigns. The figure shows that the medians of the $\mathrm{NO}_{\mathrm{x}}$ 

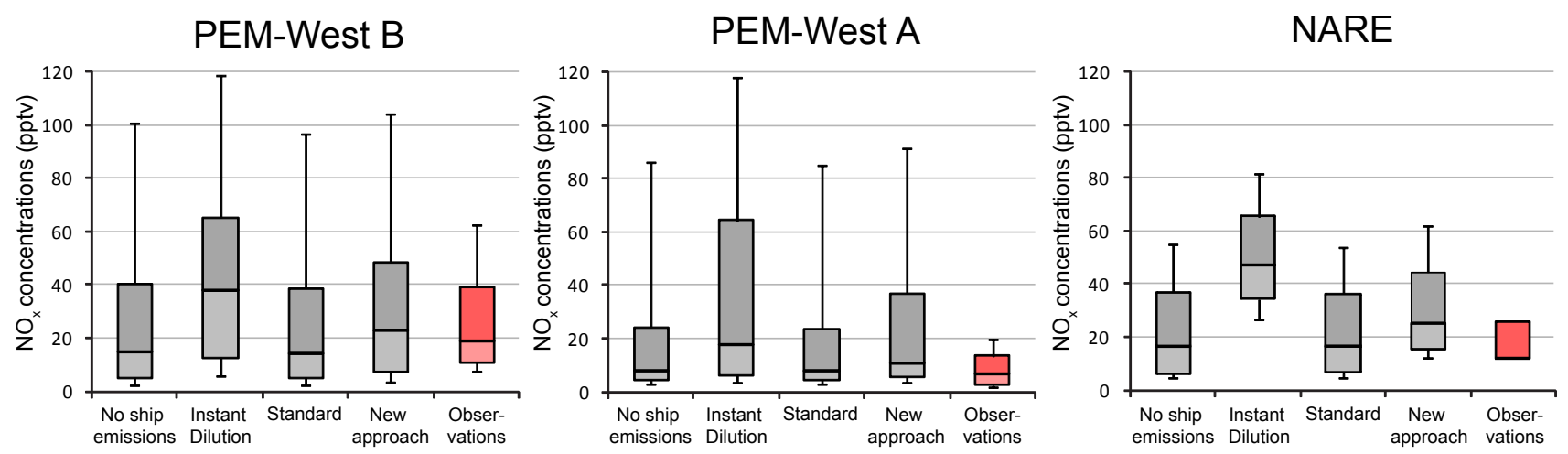

Fig. 4. Box \& Whisker plot of simulated and observed median $\mathrm{NO}_{\mathrm{x}}$ concentrations (in pptv) for the PEM-West B campaign (left), the PEM-West A campaign (middle) and the NARE campaign (right), averaged over the lower $1.2 \mathrm{~km}$. Each box shows the data between the upper and lower quartiles (25th and 75th percentile), with the median represented by a horizontal line; whiskers go out to the 5th and 95th percentile of the data. PEM-West B measurements were taken from 7 February till 14 March 1994, PEM-West A measurements were taken from 16 September till 21 October 1991, and NARE measurements were taken during September 1994. Simulations were performed for the year 2005. The PEM-West A and PEM-West B data was obtained from the Atmospheric Chemistry Division, National Center for Atmospheric Research, University Corporation for Atmospheric Research (available at http://cdp.ucar.edu/). For the NARE campaign we use statistics reported in Kasibhatla et al. (2000). We converted all $\mathrm{NO}$ measurements into $\mathrm{NO}_{\mathrm{x}}$ concentrations using the $\frac{\mathrm{NO}}{\mathrm{NO}_{\mathrm{x}}}$ ratio derived from GEOS-Chem simulations.

PEM-West B

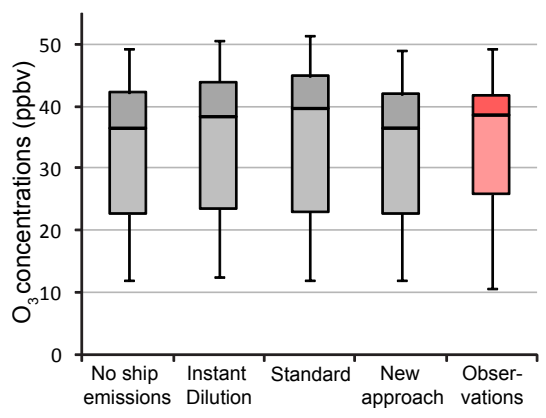

PEM-West A

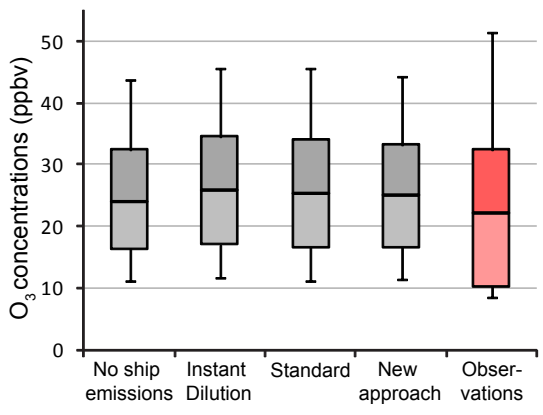

Fig. 5. Box \& Whisker plot of simulated and observed median $\mathrm{O}_{3}$ concentrations (in ppbv) for the PEM-West B campaign (left) and the PEM-West A campaign (right).

concentrations simulated with our LUT approach are in between the values simulated with the instant dilution and no ship emissions model for all campaigns. For PEM-West B, $\mathrm{NO}_{\mathrm{x}}$ concentrations simulated with our new approach (median value of $23 \mathrm{pptv}$ ) are closest to observations (median 19 pptv). It is obvious that the standard model (median 14 pptv) and model without ship emissions (median $15 \mathrm{pptv}$ ) simulate too little $\mathrm{NO}_{\mathrm{x}}$, and the instant dilution model (median 38 pptv) strongly overestimates the amount of $\mathrm{NO}_{\mathrm{x}}$. Using a Mann-Whitney-Wilcoxon test, we found that for PEMWA, PEMWB and NARE the difference in $\mathrm{NO}_{\mathrm{x}}$ concentrations between the standard approach and the model without ship emissions is statistically insignificant $(\alpha$ level of 0.05). For PEMWA, PEMWB and NARE, the difference in $\mathrm{NO}_{\mathrm{x}}$ concentrations between all other simulations was sta- tistically significant ( $\alpha$ level of 0.05 ). Temporal mismatches are likely to contribute to the differences between simulated and observed values. However, it is obvious that over both oceans, the standard model simulates too little $\mathrm{NO}_{\mathrm{x}}$, and that the instant dilution model always simulates too much $\mathrm{NO}_{\mathrm{x}}$.

Figure 5 shows a comparison of simulated and observed $\mathrm{O}_{3}$ concentrations in the marine boundary layer for the PEM-West $\mathrm{A}$ and PEM-West $\mathrm{B}$ campaign. $\mathrm{O}_{3}$ observations for the NARE campaign were not available in Kasibhatla et al. (2000), and we did not include simulations for this campaign. For both PEM-West A and PEM-West $\mathrm{B}$, the standard model (with median values of $25.2 \mathrm{ppbv}$ and $39.6 \mathrm{ppbv}$, respectively) and the instant dilution model (medians $26.0 \mathrm{ppbv}$ and $38.3 \mathrm{ppbv}$ ) simulate the highest $\mathrm{O}_{3}$ concentrations. For spring conditions (PEM-West B), the 

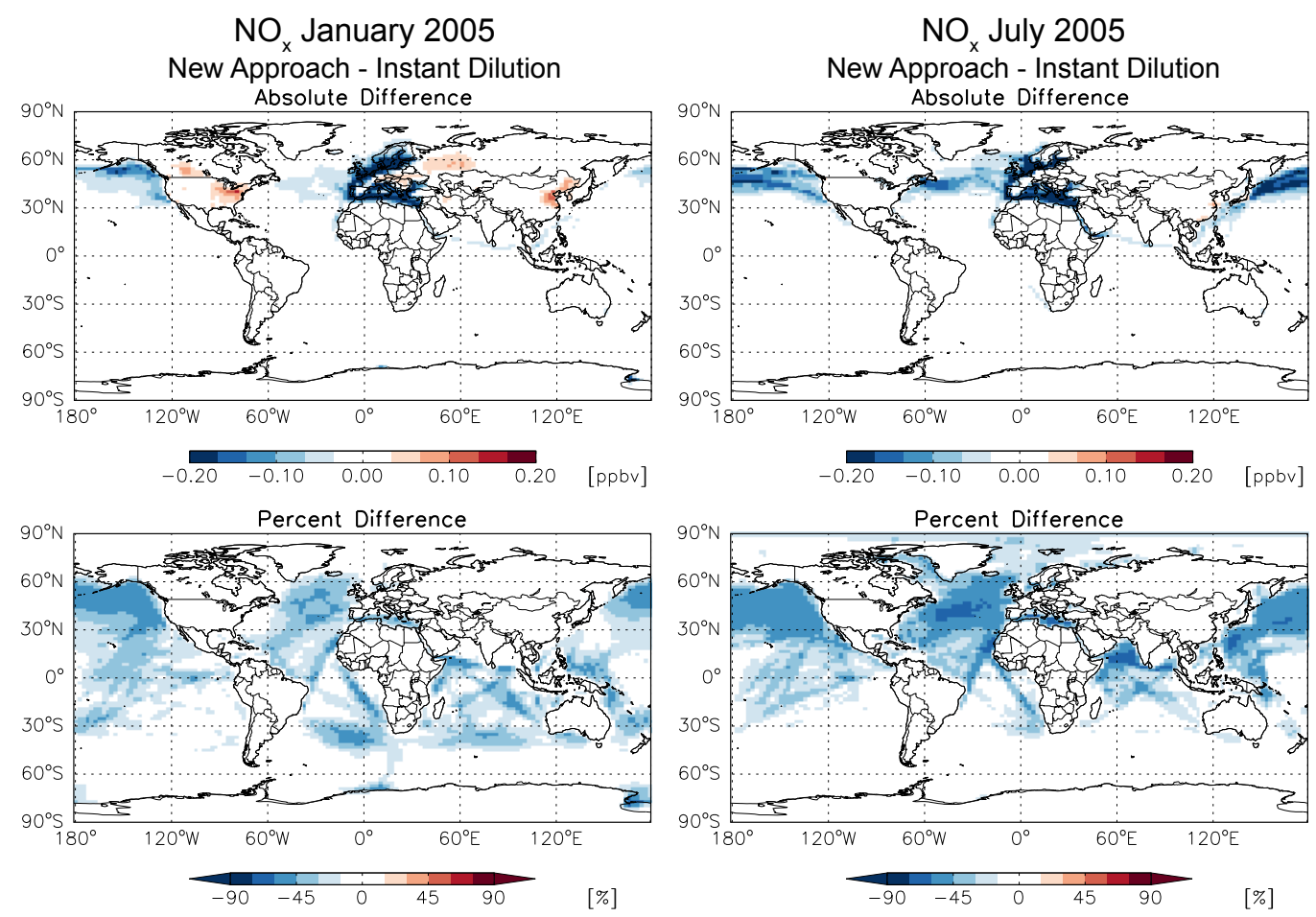

Fig. 6. Differences between instant dilution and plume-in-grid simulations of $\mathrm{NO}_{\mathrm{x}}$ concentrations in January and July 2005 . Results are shown for the lowest GEOS-Chem model layer $(0-0.12 \mathrm{~km})$.
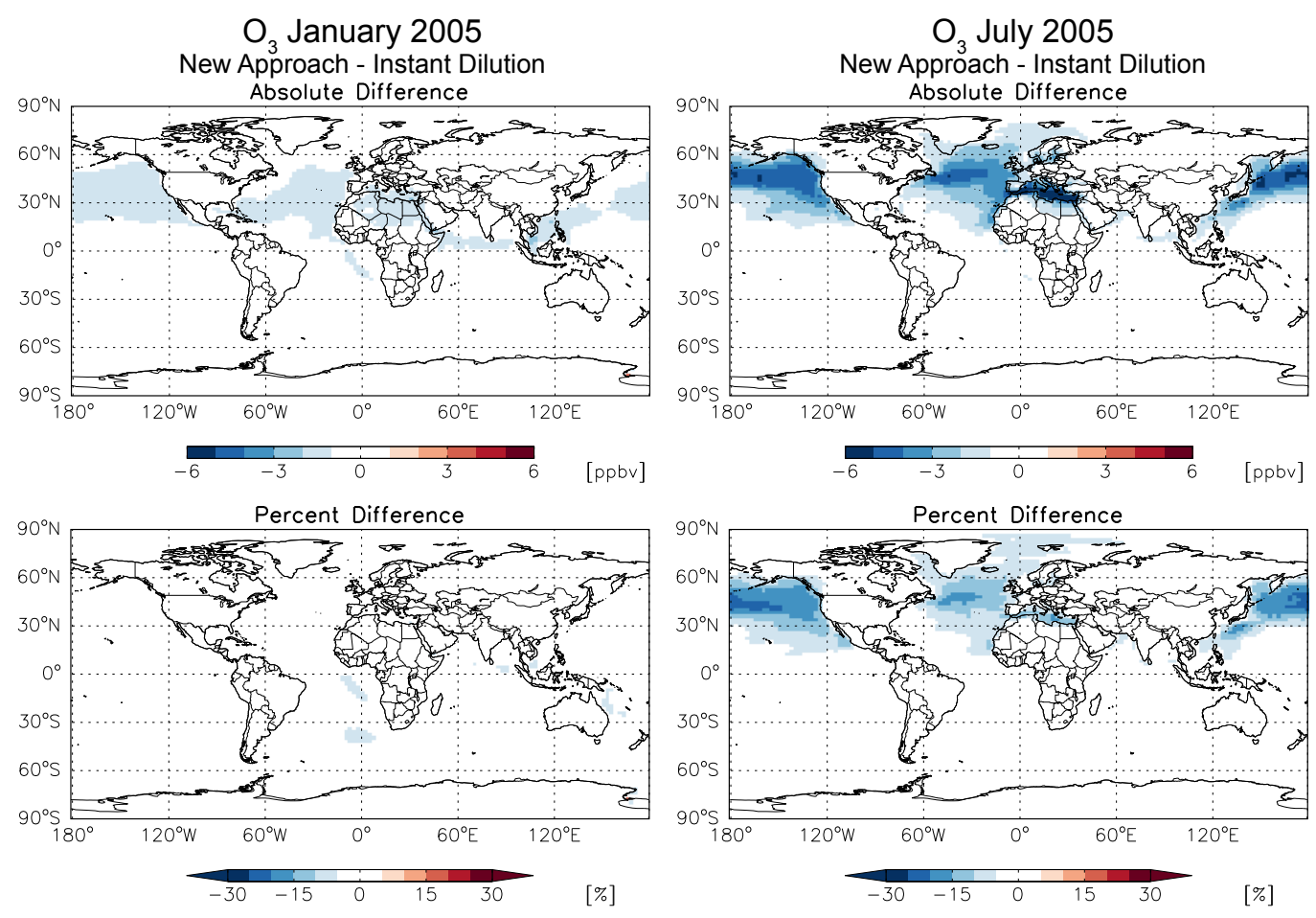

Fig. 7. Differences between instant dilution and plume-in-grid simulations of $\mathrm{O}_{3}$ concentrations in January and July 2005. Results are shown for the lowest GEOS-Chem model layer $(0-0.12 \mathrm{~km})$. 
standard model simulates the highest $\mathrm{O}_{3}$ concentrations, as a consequence of its continuous $\mathrm{O}_{3}$ production, also during darkness. The simulation without any ship emissions produces the smallest $\mathrm{O}_{3}$ concentrations (medians $24.0 \mathrm{ppbv}$ and $36.4 \mathrm{ppbv}$ ), and the difference of $0.1 \mathrm{ppbv}$ (for PEM-West B) and 1 ppbv (for PEM-West A) with our new approach suggests that the overall effect of ships on springtime $\mathrm{O}_{3}$ over the North Pacific is only small. As we have only a limited amount of observations in our comparison, and as there is a temporal mismatch, we cannot conclude a best match of any simulations with the $\mathrm{O}_{3}$ observations.

Both comparisons show that our new approach reduces $\mathrm{NO}_{\mathrm{x}}$ and $\mathrm{O}_{3}$ concentrations compared to the instant dilution approach, and simulates $\mathrm{NO}_{\mathrm{x}}$ concentrations that are in better agreement with observations. $\mathrm{O}_{3}$ concentrations simulated with our method are comparable to the other simulations.

\subsection{Comparison of different GEOS-Chem simulations}

Figure 6 shows the differences between the monthly mean (24 h mean) global $\mathrm{NO}_{\mathrm{x}}$ concentrations for January and July 2005 for the new LUT approach simulations and the instant dilution model simulations, for the lowest model layer $(0-0.12 \mathrm{~km})$.

The upper panels indicate that the new approach leads to $\mathrm{NO}_{\mathrm{x}}$ concentrations that are lower by $0.1-0.2 \mathrm{ppbv}(50 \%)$ than the instant dilution simulation above ship track areas over the oceans, reflecting the in-plume $\mathrm{NO}_{\mathrm{x}}$ destruction that is neglected in the instant dilution model. The reductions can be clearly seen as almost straight lines across ocean basins. Above continental polluted areas (where chemistry is identical between the new approach and instant dilution), the new approach simulation leads to higher $\mathrm{NO}_{\mathrm{x}}$ concentrations (by $\sim 0.1 \mathrm{ppbv}$ ), but the relative differences over these polluted areas are negligible. In January, average $\mathrm{NO}_{\mathrm{x}}$ concentrations in the new approach simulation are $44 \%$ lower than in the instant dilution simulation over a latitude and longitude range of $20-40^{\circ} \mathrm{W}$ and $40-50^{\circ} \mathrm{N}$ in the North Atlantic. In July, $\mathrm{NO}_{\mathrm{x}}$ concentrations simulated with the new approach are, on average, $60 \%$ lower than in the instant dilution simulation in the $20-40^{\circ} \mathrm{W}$ and $40-50^{\circ} \mathrm{N}$ box in the North Atlantic.

Figure 7 shows the differences in the monthly mean global $\mathrm{O}_{3}$ concentrations for January and July 2005. In January, the new approach simulates less $\mathrm{O}_{3}$ (about 1 to $1.5 \mathrm{ppbv}$ or $5 \%$ ) over the oceans compared to the instantly dilution model, and 0.5 to 1 ppbv (2-4\%) less $\mathrm{O}_{3}$ over large regions of the Northern Hemisphere. Over coastal waters in western Europe, our new approach simulates 0.5 to 1 ppbv lower $\mathrm{O}_{3}$ concentrations. For comparison, Huszar et al. (2010) found $\mathrm{O}_{3}$ concentrations lower by 0.4 to 0.7 ppbv over these areas during winter. In July, as a result of lower $\mathrm{NO}_{\mathrm{x}}$ concentrations, the new approach simulation shows lower $\mathrm{O}_{3}$ concentrations (up to 5 ppbv, or 10-25\%) over the oceans. Relative differences decrease over strongly polluted areas (e.g. North Sea or coastal China). In July, the new approach simulates $25 \%$ lower $\mathrm{NO}_{\mathrm{x}}$ concentrations in the North Sea compared to the instant dilution model, and only $3 \%$ lower $\mathrm{O}_{3}$ concentrations.

Figure 8 compares our new LUT approach and the standard GEOS-Chem model. In both January and July, our new approach simulates higher $\mathrm{NO}_{\mathrm{x}}$ concentrations over the oceans (up to $0.2 \mathrm{ppbv}$ ), which is expected because the standard model releases all ship $\mathrm{NO}_{\mathrm{x}}$ emissions as $10 \mathrm{O}_{3}$ molecules and 1 molecule $\mathrm{HNO}_{3}$. Relative differences are strongest over the Northern Hemisphere (up to a factor 12 in July over the North Atlantic). Averaged over the box in the North Atlantic in July, our LUT approach simulates higher $\mathrm{NO}_{\mathrm{x}}$ concentrations by $43 \mathrm{pptv}$ (factor 6).

Figure 9 shows the differences between the monthly mean global $\mathrm{O}_{3}$ concentrations for January and July 2005. In January, our new approach simulates lower $\mathrm{O}_{3}$ concentrations over the entire Northern Hemisphere (1-6 ppbv or 5-30\%). This is due to the fact that the standard model releases 10 $\mathrm{O}_{3}$ molecules per $\mathrm{NO}_{\mathrm{x}}$ molecule emitted, even in darkness, whereas our LUT approach accounts for weaker photochemistry by lower photolysis values and temperature in wintertime and at night. In July, our new approach simulates much lower $\mathrm{O}_{3}$ concentrations over the Mediterranean Sea and other polluted European seas. This is due to the fact that the standard model always releases $10 \mathrm{O}_{3}$ molecules, and our model is releasing very little $\mathrm{O}_{3}$ over strongly polluted areas like the Mediterranean Sea. By contrast, over the Pacific Ocean, our new approach simulates higher $\mathrm{O}_{3}$ concentrations than the standard model, indicative of the daily averaged integrated NOPE being higher than the value of 10 used in the standard GEOS-Chem model, i.e. photochemical $\mathrm{O}_{3}$ production over the subtropical Pacific Ocean is, on average, more efficient than in the single plume study by Chen et al. (2005). Averaged over the box in the North Atlantic, our LUT approach simulates lower $\mathrm{O}_{3}$ concentrations by 4 ppbv $(10 \%)$ in January, while in July differences are smaller ( $0.6 \mathrm{ppbv}$ or $3 \%)$.

Figure 10 shows the differences between the monthly mean global $\mathrm{NO}_{\mathrm{x}}$ and $\mathrm{O}_{3}$ concentrations for January and July 2005 for the new LUT approach and the simulation without ship emissions, for the lowest model layer $(0-0.12 \mathrm{~km})$. In January, our new approach simulates higher $\mathrm{NO}_{\mathrm{x}}$ concentrations than the simulation without ship emissions, both over the oceans and over polluted areas. We attribute the increased $\mathrm{NO}_{\mathrm{x}}$ concentrations over Europe to the reduced $\mathrm{O}_{3}$ concentrations here (by less than $0.5 \mathrm{ppbv}$, invisible on the colour scale for the lower left panel of Fig. 10). The difference in $\mathrm{O}_{3}$ concentrations over the oceans in January is small, suggesting the effect of ship emissions in winter is only weak. In July the new approach simulation shows higher $\mathrm{NO}_{\mathrm{x}}$ concentrations than the simulation without ship $\mathrm{NO}_{\mathrm{x}}$ emissions. $\mathrm{NO}_{\mathrm{x}}$ concentrations in the new approach simulation are, on average, $7 \times$ higher ( $44 \mathrm{pptv}$ ) averaged over the box in the North Atlantic in July. Over this box in the North Atlantic, ships contribute $4 \mathrm{ppbv}(15 \%)$ to summertime $\mathrm{O}_{3}$ concentrations. 

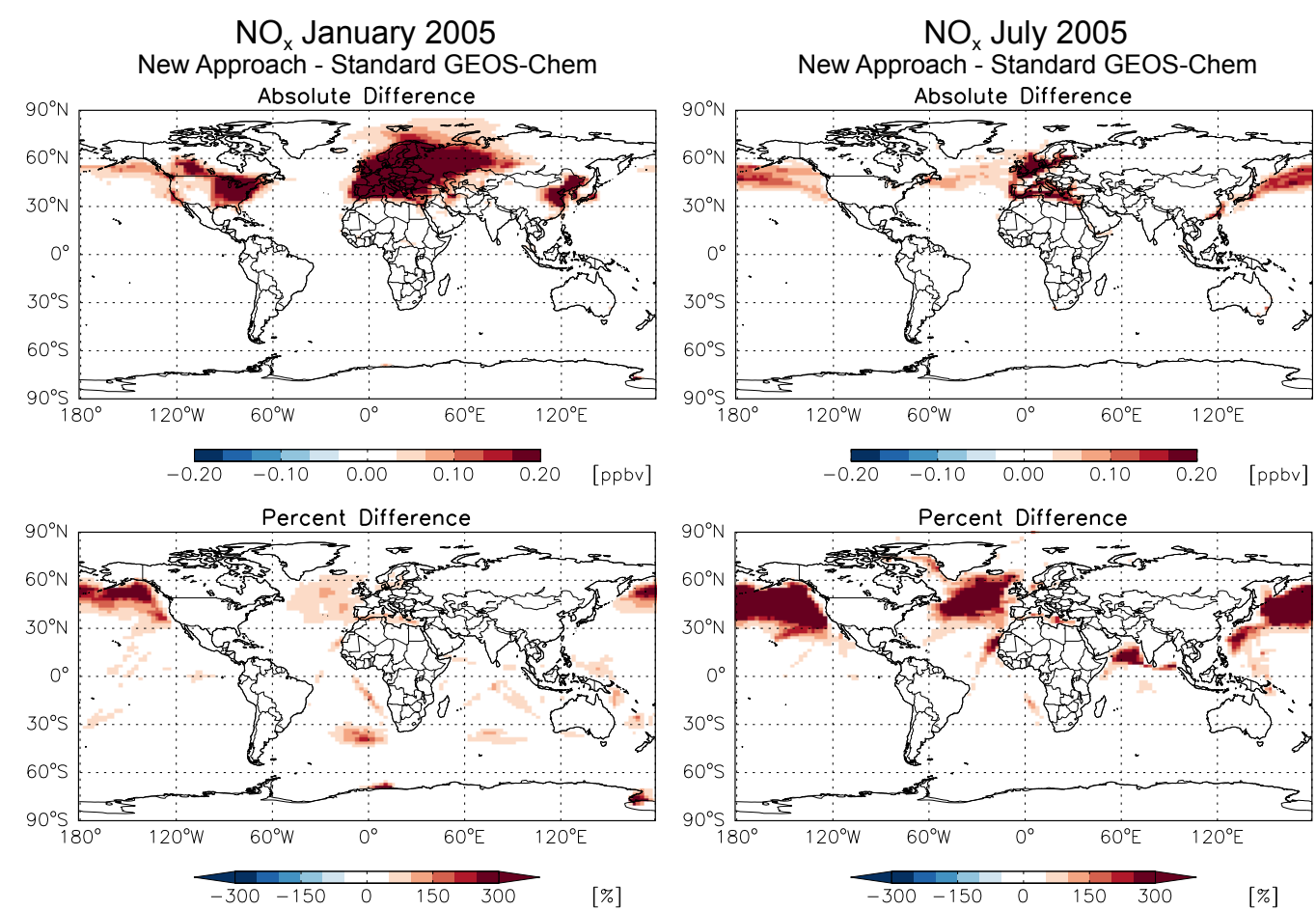

Fig. 8. Differences between standard GEOS-Chem and plume-in-grid simulations of $\mathrm{NO}_{\mathrm{x}}$ concentrations in January and July 2005. Results are shown for the lowest GEOS-Chem model layer $(0-0.12 \mathrm{~km})$.
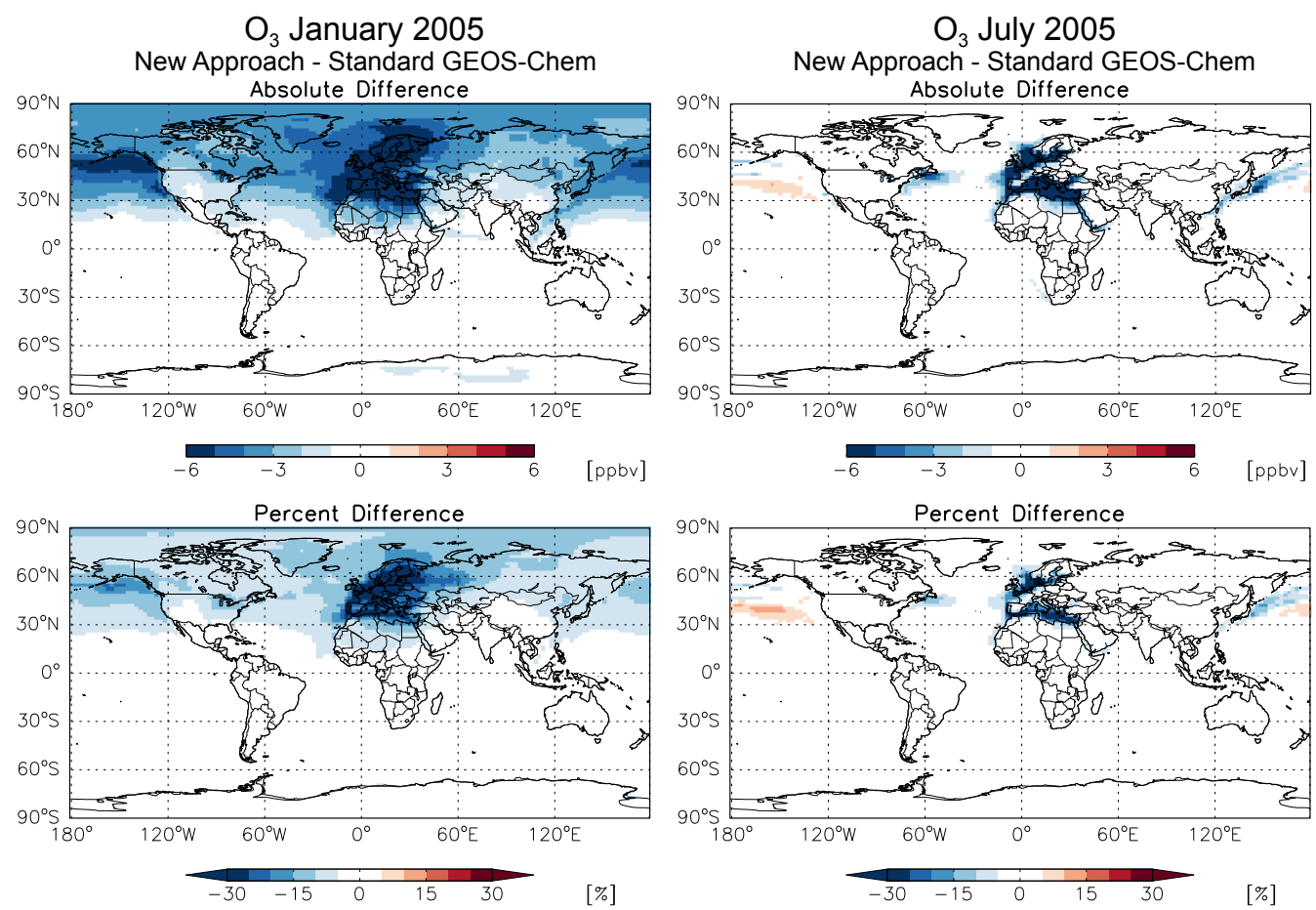

Fig. 9. Differences between standard GEOS-Chem and plume-in-grid simulations of $\mathrm{O}_{3}$ concentrations in January and July 2005. Results are shown for the lowest GEOS-Chem model layer $(0-0.12 \mathrm{~km})$. 

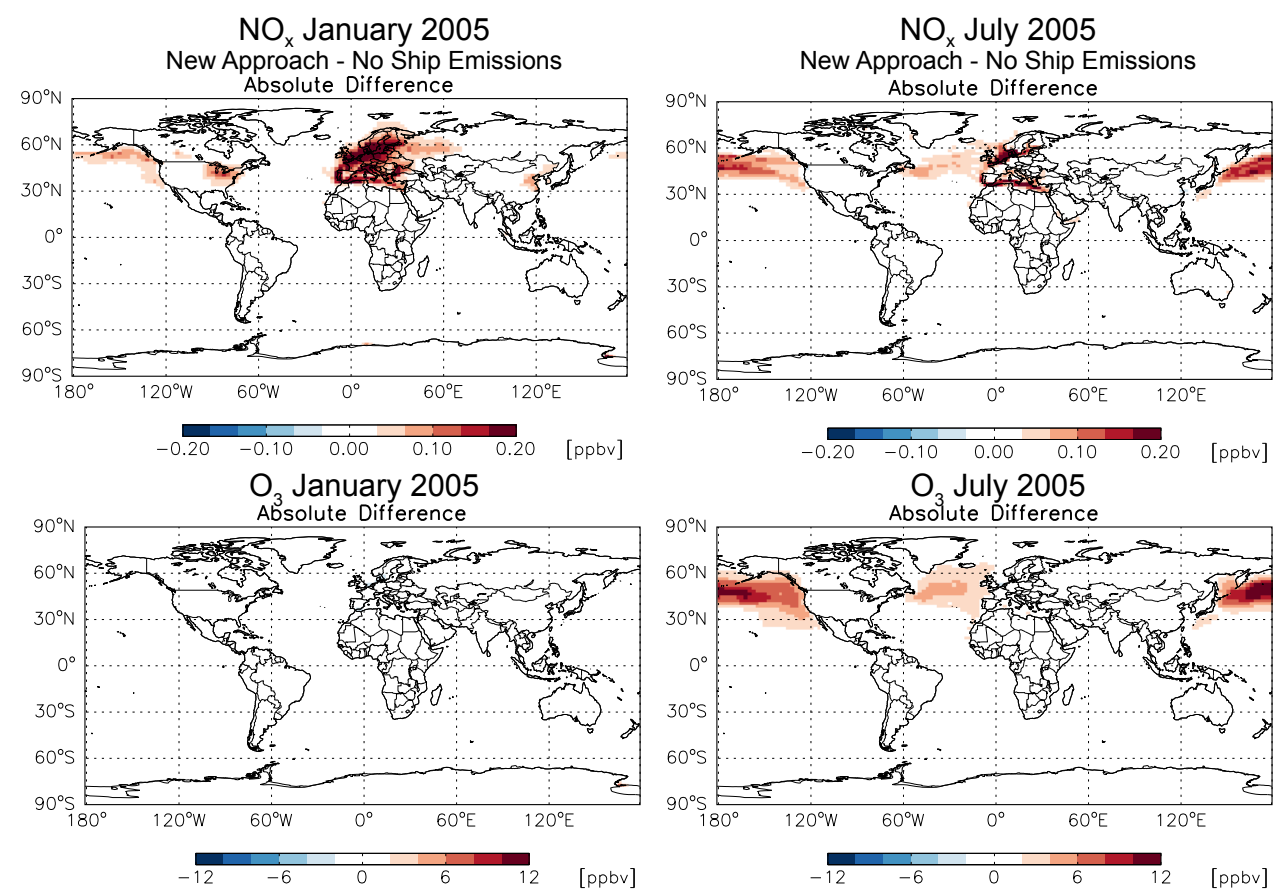

Fig. 10. Absolute differences between simulations without ship emissions and plume-in-grid simulations of $\mathrm{NO}_{\mathrm{x}}$ and $\mathrm{O}_{3}$ concentrations in January and July 2005. Results are shown for the lowest GEOS-Chem model layer $(0-0.12 \mathrm{~km})$.

\section{Conclusions}

We presented a computationally efficient approach to take the non-linear chemical effects that occur during the dispersion of $\mathrm{NO}_{\mathrm{x}}$ emitted by ships into account in coarse-gridded global 3-D chemistry transport models (CTMs). Our approach uses a plume-in-grid treatment of ship emissions, with simulations from a plume dispersion model that takes the effects of non-linear chemistry fully into account. In addition to reduced $\mathrm{NO}_{\mathrm{x}}$ emissions, the secondary compounds $\mathrm{O}_{3}$ and $\mathrm{HNO}_{3}$, produced during the $5 \mathrm{~h}$ after emission, are released into the global model.

To simulate the in-plume effects, we use the 10-ring Gaussian plume dispersion PARANOX model with state-ofscience chemical rate constants, updated emissions, photolysis constants, and dispersion parameters relevant for the marine boundary layer. We evaluated simulations by the PARANOX model against in situ aircraft observations of $\mathrm{NO}_{\mathrm{x}}, \mathrm{O}_{3}$, and (inferred) $\mathrm{OH}$ concentrations within fresh ship plumes off the coast of California in May 2002, and found that PARANOX captures the essence of ship-plume chemistry.

A sensitivity analysis showed that plume-in-grid simulations depend critically on ambient temperature, ozone concentration, $\mathrm{NO}_{\mathrm{x}}$ concentration, a solar zenith at the time of initial, and actual ( $5 \mathrm{~h}$ after) release, and photolysis rate constants for $\mathrm{NO}_{2}$ and $\mathrm{O}\left({ }^{1} \mathrm{D}\right)$.

Our approach couples the plume dispersion model PARANOX to a global model, here the 3-D GEOS-Chem CTM, in a computationally efficient manner. For every grid cell with non-zero ship $\mathrm{NO}_{\mathrm{x}}$ emissions, the global model chemical simulations provide the relevant environmental parameters, and we subsequently retrieve the matching fraction of $\mathrm{NO}_{\mathrm{x}}$ remaining and secondary species from a look-up table, calculated with PARANOX for a predefined set of environmental parameters. We then use the fraction of $\mathrm{NO}_{\mathrm{x}}$ remaining to reduce the original ship $\mathrm{NO}_{\mathrm{x}}$ emissions, and release the $\mathrm{O}_{3}$ and $\mathrm{HNO}_{3}$ produced during plume dispersion into the GEOS-Chem background state.

We adapted the GEOS-Chem model to also include options to simulate ship emissions with the widely used "instant dilution" approach, and without any ship emissions at all. Together with the standard model (that emits a ship $\mathrm{NO}_{\mathrm{x}}$ molecule as $1 \mathrm{HNO}_{3}$ and $10 \mathrm{O}_{3}$ molecules), and the improved model with the plume-in-grid approach, this provides an ensemble that allowed for a comprehensive intercomparison, as well as an evaluation against observations from (historical) aircraft campaigns over the Pacific Ocean (PEM-West A and PEM-West B) and over the North Atlantic (NARE).

We found that our improved version of GEOS-Chem simulates up to $0.1 \mathrm{ppbv}$ more $\mathrm{NO}_{\mathrm{x}}$ over the North Atlantic in July compared to simulations without ship $\mathrm{NO}_{\mathrm{x}}$ emissions, indicating that ships contribute up to $90 \%$ to total nitrogen oxide concentrations over this region. Compared to simulations using the instant dilution approach, our $\mathrm{NO}_{\mathrm{x}}$ concentrations are $0.05-0.15 \mathrm{ppbv}$ lower, indicating that models 
using instant dilution overestimate $\mathrm{NO}_{\mathrm{x}}$ over the North Atlantic by approximately $50 \%$ in July. These conclusions are supported by a comparison of simulated and observed $\mathrm{NO}_{\mathrm{x}}$ concentrations in the lower marine atmosphere (PEM-West B). We found that our improved model matches the observed $\mathrm{NO}_{\mathrm{x}}$ concentrations best, whereas the instant dilution model overestimates $\mathrm{NO}_{\mathrm{x}}$ by a factor of 2 , and the model without ship emissions underestimates $\mathrm{NO}_{\mathrm{x}}$ by $30 \%$.

Our improved model simulates up to 4 ppbv (15\%) more $\mathrm{O}_{3}$ over the North Atlantic during summer than the model without ship emissions. Ship emissions in winter have little effect on $\mathrm{O}_{3}$ over the oceans. Ozone concentrations simulated with the improved model are 3-5 ppbv (10-25\%) lower than with the instant dilution approach over the Atlantic Ocean, clearly indicating that instant dilution not only overestimates nitrogen oxides, but also ozone. Over the strongly polluted North Sea, the improved simulation shows smaller ozone reductions of $1-2 \mathrm{ppbv}(<5 \%)$ compared to the instant dilution approach, suggesting that accounting for non-linear in-plume chemistry is most relevant for pristine, unpolluted areas.

We anticipate that our method could be further improved by increasing the number of dependencies and the number of entries (to reduce interpolation error) in our look-up table. We expect that taking into account $5 \mathrm{~h}$ integrated environmental parameters (instead of end-of-run) would improve the accuracy of individual instantaneous simulations, but at the expense of significant additional memory requirements. However, with increasing memory of computers this could well become possible.

Acknowledgements. This research was funded by the Netherlands Organisation for Scientific Research, NWO Vidi grant 864.09.001. Work at Harvard was funded by the NASA Atmospheric Composition Modeling and Analysis Program.

Edited by: C. Han Song

\section{References}

Bey, I., Jacob, D. J., Yantosca, R. M., Logan, J. A., Field, B. D., Fiore, A. M., Li, Q., Liu, H. Y., Mickley, L. J., and Schultz, M. G.: Global modeling of tropospheric chemistry with assimilated meteorology: Model description and evaluation, J. Geophys. Res., 106, 23073-23095, 2001.

Charlton-Perez, C. L., Evans, M. J., Marsham, J. H., and Esler, J. G.: The impact of resolution on ship plume simulations with $\mathrm{NO}_{\mathrm{x}}$ chemistry, Atmos. Chem. Phys., 9, 7505-7518, doi:10.5194/acp-9-7505-2009, 2009.

Chen, G., Huey, L. G., Trainer, M., Nicks, D., Corbett, J., Ryerson, T., Parrish, D., Nueman, J. A., Nowak, J., Tanner, D., Holloway, J., Brock, C., Crawford, J., Olson, J. R., Sullivan, A., Weber, R., Schauffler, S., Donnelly, S., Atlas, E., Roberts, J., Flocke, F., Hübler, G., and Fehsenfeld, F.: An investigation of the chemistry of ship emissions plumes during ITCT 2002, J. Geophys. Res., 110, D10S90, doi:10.1029/2004JD005236, 2005.
Corbett, J. J., Fischbeck, P. S., and Pandis, S. N.: Global nitrogen and sulfur inventories for oceangoing ships, J. Geophys. Res., 104, 3457-3470, 1999.

Corbett, J. J., Winebrake, J. J., Green, E. H., Kasibhatla, P., Eyring, V., and Lauer, A.: Mortality from Ship Emissions: A Global Assessment, Environ. Sci. Technol., 41, 8512-8518, 2007.

Davis, D. D., Grodzinsky, G., Kasibhatla, P., Crawford, J., Chen, G., Liu, S., Bandy, A., Thornton, D., Guan, H., and Sandholm, S.: Impact of Ship Emissions on Marine Boundary Layer $\mathrm{NO}_{\mathrm{x}}$ and $\mathrm{SO}_{2}$ Distributions over the Pacific Basin, Geophys. Res. Lett., 28, 235-238, 2001.

DeMore, W. B., Sander, S. P., Golden, D. M., Hampson, R. F., Kurylo, M. J., Howard, C. J., Ravishankara, A. R., and Kolb, C. E.: Chemical kinetics and photochemical data for use in stratospheric modeling, JPL-Publ., 97-4, 1997.

Duncan, B. N., West, J. J., Yoshida, Y., Fiore, A. M., and Ziemke, J. R.: The influence of European pollution on ozone in the Near East and northern Africa, Atmos. Chem. Phys., 8, 2267-2283, doi:10.5194/acp-8-2267-2008, 2008.

Evans, M. J. and Jacob, D. J.: Impact of new laboratory studies of $\mathrm{N}_{2} \mathrm{O}_{5}$ hydrolysis on global model budgets of tropospheric nitrogen oxides, ozone and OH, Geophys. Res. Lett., 32, L09813, doi:10.1029/2005GL022469, 2005.

Eyring, V., Köhler, H. W., van Aardenne, J., and Lauer, A.: Emissions from international shipping: 1 . The last 50 years, J. Geophys. Res., 110, D17305, doi:10.1029/2004JD005619, 2005.

Eyring, V., Isaksen, I. S. A., Berntsen, T., Collins, W. J., Corbett, J. J., Endresen, O., Grainger, R. G., Moldanova, J., Schlager, H., and Stevenson, D. S.: Transport impacts on atmosphere and climate: Shipping, Atmos. Environ., 44, 4735-4771, 2010.

Franke, K., Eyring, V., Sander, R., Hendricks, J., Lauer, A., and Sausen, R.: Toward effective emissions of ships in global models, Meteorol. Z., 17, 117-129, 2008.

Hanna, S. R., Schulman, L. L., Paine, R. J., and Pleim, J. E.: Development and Evaluation of the Offshore and Coastal Dispersion Model, J. Air Pollut. Control Assoc., 35, 1039-1047, 1985.

Hoell, J. M., Davis, D. D., Lui, S. C., Newell, R., Shipham, M., Akimoto, H., McNeal, R. J., Bendura, R. J., and Drewry, J. W.: Pacific Exploratory Mission-West A (PEM-West A): SeptemberOctober 1991, J. Geophys. Res., 101, 1641-1653, 1996.

Hoell, J. M., Davis, D. D., Lui, S. C., Newell, R. E., Akimoto, H., McNeal, R. J., and Bendura, R. J.: Pacific Exploratory MissionWest Phase B: Feburary-March 1994, J. Geophys. Res., 102, 28223-28239, 1997.

Huszar, P., Cariolle, D., Paoli, R., Halenka, T., Belda, M., Schlager, H., Miksovsky, J., and Pisoft, P.: Modeling the regional impact of ship emissions on $\mathrm{NO}_{\mathrm{x}}$ and ozone levels over the Eastern Atlantic and Western Europe using ship plume parameterization, Atmos. Chem. Phys., 10, 6645-6660, doi:10.5194/acp-10-66452010, 2010.

IPCC 2007, Climate Change 2007: Impacts, Adaptation and Vulnerability. Contribution of Working Group II to the Fourth Assessment Report of the Intergovernmental Panel on Climate Change, edited by: Parry, M. L., Canziani, O. F., Palutikof, J. P., van der Linden, P. J., and Hanson, C. E., Cambridge University Press, Cambridge, UK, 976 pp., 2007.

Kasibhatla, P., II, H. L., Moxim, W. J., Pandis, S. N., Corbett, J. J., Peterson, M. C., Honrath, R. E., Frost, G. J., Knapp, K., Parrish, D. D., and Ryerson, T. B.: Do emissions from ships have 
a significant impact on concentrations of nitrogen oxides in the marine boundary layer?, Geophys. Res. Lett., 27, 2229-2232, 2000.

Kim, H. S., Song, C. H., Park, R. S., Huey, G., and Ryu, J. Y.: Investigation of ship-plume chemistry using a newly-developed photochemical/dynamic ship-plume model, Atmos. Chem. Phys., 9, 7531-7550, doi:10.5194/acp-9-7531-2009, 2009.

Kondo, Y., Ziereis, H., Koike, M., Kawakami, S., Gregory, G. L., Sachse, G. W., Singh, H. B., Davis, D. D., and Merril, J. T.: Reactive nitrogen over the Pacific Ocean during PEM-West A, J. Geophys. Res., 101, 1809-1828, 1996.

Lawrence, M. G. and Crutzen, P. J.: Influence of $\mathrm{NO}_{\mathrm{x}}$ emissions from ships on tropospheric photochemistry and climate, Nature, 402, 167-170, 1999.

Marmer, E., Dentener, F., Aardenne, J. v., Cavalli, F., Vignati, E., Velchev, K., Hjorth, J., Boersma, F., Vinken, G., Mihalopoulos, N., and Raes, F.: What can we learn about ship emission inventories from measurements of air pollutants over the Mediterranean Sea?, Atmos. Chem. Phys., 9, 6815-6831, doi:10.5194/acp-96815-2009, 2009.

Meijer, E. W.: Modelling the impact of subsonic aviation on the composition of the atmosphere, Ph.D. thesis, Eindhoven University of Technology, 2001.

Meijer, E. W., van Velthoven, P. F. K., Wauben, W. M. F., Beck, J. P., and Velders, G. J. M.: The effects of the conversion of nitrogen oxides in aircraft exhaust plumes in global models, Geophys. Res. Lett., 24, 3013-3016, 1997.

Ryerson, T. B., Huey, L. G., Knapp, K., Neuman, J. A., Parrish, D. D., Sueper, D. T., and Fehsenfeld, F. C.: Design and initial characterization of an inlet for gas-phase $\mathrm{NO}_{\mathrm{y}}$ measurements from aircraft, J. Geophys. Res., 104, 5483-5492, 1999.

Schlager, H., Baumann, R., Lichtenstern, M., Petzold, A., Arnold, F., Speidel, M., Gurk, C., and Fischer, H.: Aircraft-based trace gas measurements in a primary European ship corridor, Proceedings of the International Conference on Transport, Atmosphere and Climate (TAC), Oxford, UK, 83-88, 2008.
Sillman, S., Logan, J. A., and Wofsy, S. C.: A regional scale model for ozone in the United States with subgrid representation of urban and power plant plumes, J. Geophys. Res., 95, 5731-5748, 1990.

Song, C. H., Chen, G., Hanna, S. R., Crawford, J., and Davis, D. D.: Dispersion and chemical evolution of ship plumes in the marine boundary layer: Investigation of $\mathrm{O}_{3} / \mathrm{NO}_{\mathrm{y}} / \mathrm{HO}_{\mathrm{x}}$ chemistry, J. Geophys. Res., 108, 4143, doi:10.1029/2002JD002216, 2003.

Song, C. H., Kim, H. S., von Glasow, R., Brimblecombe, P., Kim, J., Park, R. J., Woo, J. H., and Kim, Y. H.: Source identification and budget analysis on elevated levels of formaldehyde within the ship plumes: a ship-plume photochemical/dynamic model analysis, Atmos. Chem. Phys., 10, 11969-11985, doi:10.5194/acp10-11969-2010, 2010.

Vestreng, V., Mareckova, K., Kakareka, S., Malchykhina, A., and Kukharchyk, T.: Inventory Review 2007; Emission Data reported to LRTAP Convention and NEC Directive, MSC-W Technical Report 1/07, Tech. rep., The Norwegian Meteorological Institute, Oslo, Norway, 2007.

Vinken, G. C. M.: Accounting for non-linear chemistry of shipping plumes in a Global Chemistry Transport Model, M.Sc.-Thesis, R-1772-A, Eindhoven University of Technology, 2010.

von Glasow, R., Lawrence, M. G., Sander, R., and Crutzen, P. J.: Modeling the chemical effects of ship exhaust in the cloudfree marine boundary layer, Atmos. Chem. Phys., 3, 233-250, doi:10.5194/acp-3-233-2003, 2003.

Wang, C., Corbett, J. J., and Firestone, J.: Improving Spatial Representation of Global Ship Emissions Inventories, Environ. Sci. Technol., 42, 193-199, 2008. 